\title{
Gemological Characterization of Peridot from Pyaung-Gaung in MOGOK, MYANMAR
}

Montira Seneewong-Na-Ayutthaya, Wassana Chongraktrakul, and Tasnara Sripoonjan

The Pyaung-Gaung area in the Mogok township of Myanmar is one of the essential sources of high-quality peridot for the international gem trade. Pyaung-Gaung peridot possesses an attractive deep olive green color and can be found in large sizes $(>10 \mathrm{ct}$ ) in the market. It has long been mined from ultramafic rocks, largely dunite, at a primary deposit near Bernard-Myo. Internal features consist mainly of circular decrepitation halos ("lily pads"), fluid inclusions, and fiber tufts. Common mineral inclusions are dark biotite-phlogopite and chromite, sometimes coexisting with serpentine, magnesite, chlorite, and talc. Pyaung-Gaung peridot also contains olivine inclusions not previously found in peridot from other locations. 2D and 3D cross-plots of the trace element contents of $\mathrm{Cr}, \mathrm{V}, \mathrm{Co}, \mathrm{Sc}$, Ni, and Ti provide helpful separations among Burmese, Chinese, and Pakistani localities.

P eridot is a gem-quality variety of the mineral forsterite. It belongs to the olivine group, an isomorphous series whose main members are forsterite (magnesium silicate, $\mathrm{Mg}_{2} \mathrm{SiO}_{4}$ ), fayalite (iron silicate, $\mathrm{Fe}_{2} \mathrm{SiO}_{4}$ ), and tephroite (manganese silicate, $\mathrm{Mn}_{2} \mathrm{SiO}_{4}$ ) (Sinkankas et al., 1992; Deer et al., 2013). It crystallizes in the orthorhombic system with a rhombus-shaped habit (figure 1, right). In general, peridot yields a range of colors, including pale yellowish green to deep green, greenish brown to brown, and rarely brown with a dull, vitreous/greasy luster. The most desired and valuable color is saturated green without any tinge of yellow or brown. The green color is caused by iron content $\left(\mathrm{Fe}^{2+}\right)$ within the structure.

Among the major modern localities, the primary sources of peridot are peridotite xenoliths in alkali basalts (United States and China) (Shen et al., 2011) and serpentinized dunites showing recrystallized olivine in tension gashes in sheared dunite bodies (Pakistan) (Bouilhol et al., 2015). Several articles have presented geological and mineralogical data for gem peridot deposits worldwide, including Zabargad (Egypt), Arizona (United States), Mogok (Myanmar),

See end of article for About the Authors and Acknowledgments.

Gems \& Gemology, Vol. 57, No. 4, pp. 318-337,

http://dx.doi.org/10.5741/GEMS.57.4.318

(C) 2021 Gemological Institute of America
Yiqisong (China), Kohistan (Pakistan), the Central Highlands of Vietnam, and localities in Ethiopia and Tanzania (Gübelin, 1981; Jan and Khan, 1996; Fuhrbach, 1998; Thuyet et al., 2016). Other studies have focused on peridot's gemological, chemical, and

\section{In Brief}

- Peridot from Pyaung-Gaung in Mogok occurred in ultramafic rocks and later recrystallized during a tectonic event.

- Various inclusions found in these peridot samples provide an indication of retrograde metamorphism and/or recrystallization.

- Tufts of very fine fibers and distinctive protogenetic olivine are found to be diagnostic inclusions in Pyaung-Gaung peridot.

- LA-ICP-MS trace element analysis can separate Pyaung-Gaung peridot from one deposit in China and another in Pakistan.

spectroscopic characteristics (e.g., Stockton and Manson, 1983; Koivula and Fryer, 1986; Fritsch and Lulzac, 2004; Adamo et al., 2009; Bouihol et al., 2015; Surour, 2018; Sripoonjan et al., 2019; Zhang et al., 2019).

Mogok is well known as one of the single most important sources of high-quality ruby, sapphire, and 


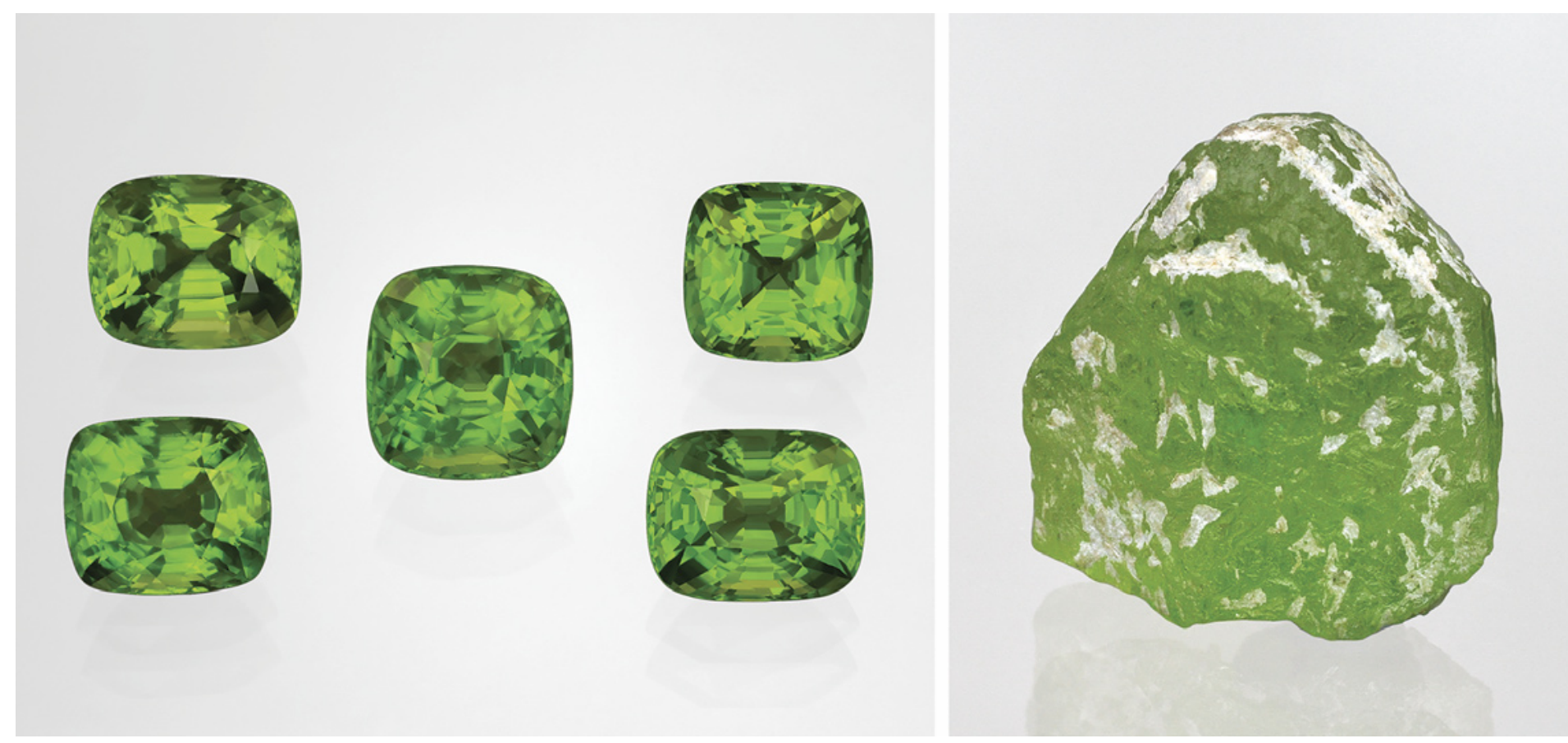

Figure 1. Left: Five faceted peridot samples from the Pyaung-Gaung mine in Mogok, Myanmar, weighing 5.18$7.52 \mathrm{ct}$, were examined in this study. Right: This $15.0 \times 16.9 \times 6.5 \mathrm{~mm}$ rough crystal showing a rhombus-shaped tabular habit and rounded faces, with minor white carbonate and talc, is also from the Pyaung-Gaung mine. Photos by T. Sripoonjan.

spinel (Kane and Kammerling, 1992; Waltham, 1999). But Mogok is also a significant supplier of large, fine peridot to the global gem trade. Mogok peridot has been known since the fifteenth century (Iyer, 1953). Its intense green is quite distinct and sometimes comparable to that of Pakistani peridot, but with a slight difference in clarity. Much of the finest-color peridot comes from Myanmar and Pakistan (GIA, n.d.).

The peridot mines at Mogok lie in the PyaungGaung, Htin-Shu Taung, and Bernard-Myo areas (Thu and Zaw, 2017). Of these, the Pyaung-Gaung mines produce the finest color and largest sizes. Pyaung-Gaung peridot is typically yellowish green, while the highest-quality stones possess a rich olive green color (figure 1). Harlow and Thu (2014) studied samples in peridotite rocks from Pyaung-Gaung and compared them with those from the original Sapat deposit of Pakistan and the ancient Zabargad Island deposit of Egypt. They suggested that Mogok peridot was recrystallized in a cavity containing hydrous fluid of olivine, with the help of Earth's tectonic activity. However, no insight into the gemological characteristics of peridot from Mogok has been widely available.

In May 2019, two of the authors (MS and TS) had the opportunity to visit the Pyaung-Gaung mine, where they witnessed the mining process, collected firsthand information, and briefly examined olivine samples on-site. The first sample group (five faceted stones and ten pieces of larger rough) was purchased from miners in the area, and additional samples were obtained through various marketing channels in Mogok. The present article provides an update on the Pyaung-Gaung peridot deposit.

\section{GEOLOGICAL SETTING}

Mogok is known as one of the world's oldest and most famous gem sources. The gem-rich area of Mogok (also known as the "Mogok Stone Tract") is located in Kathe District of Upper Burma, 200 km northeast of Mandalay (Kyaw Thu, 2007). The area is situated in the central part of the Mogok Metamorphic Belt (MMB), which is composed mainly of rocks such as marble, gneiss, quartzite, and calc-silicate, as well as various types of igneous rocks from felsic to ultramafic (Iyer, 1953; Phyo et al., 2019). The complex structure involving folds and faults indicates that Mogok has been subjected to several major tectonic processes over extended periods of time, and this yielded a wide range of mineral assemblages and gem materials (e.g., ruby, sapphire, peridot, and spinel) that 


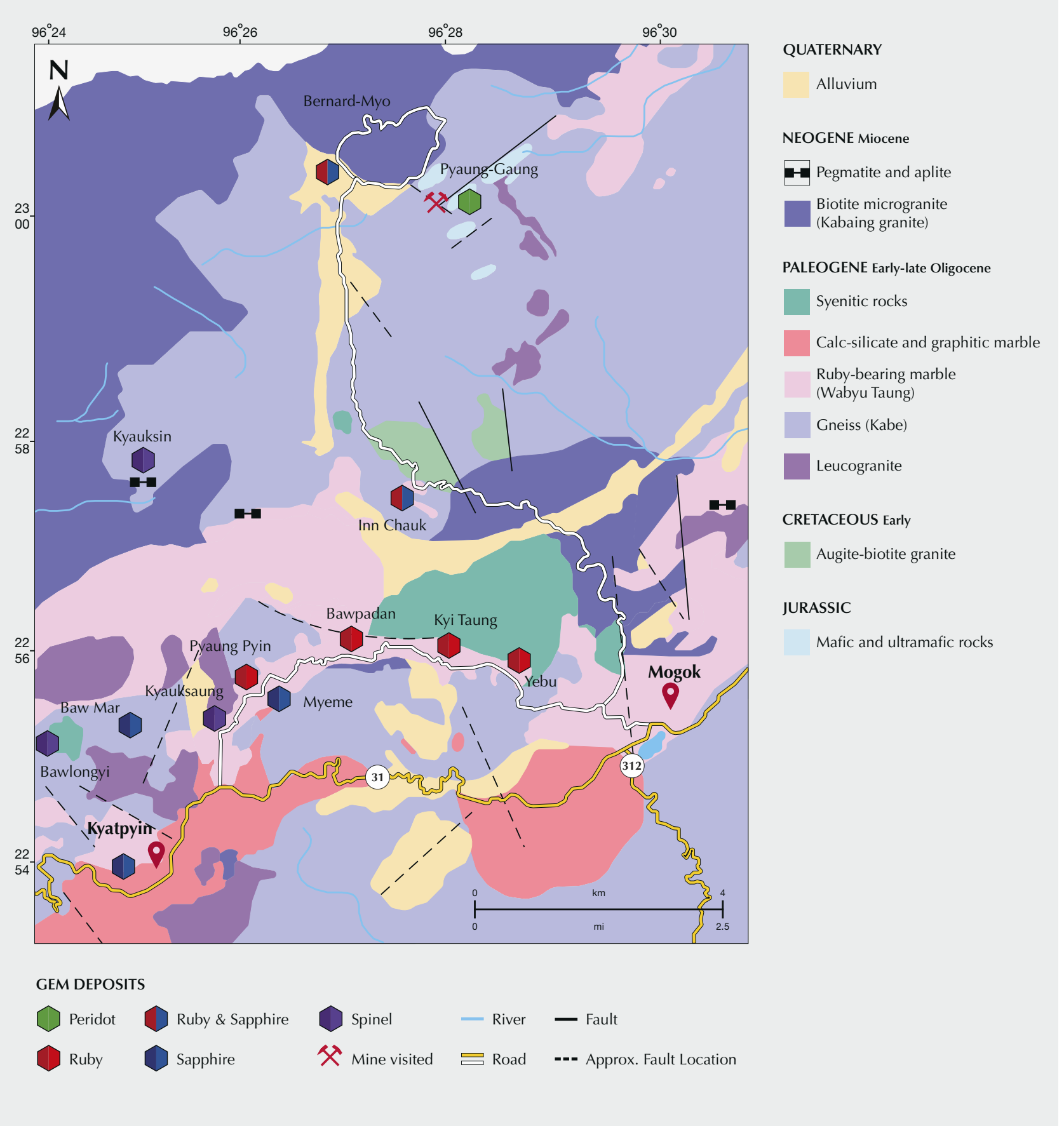

Figure 2. The Pyaung-Gaung peridot deposit is located in Bernard-Myo, north-northwest of Mogok township. Modified after Thu (2007), Themelis (2008), and Kan-Nyunt et al. (2013).

are the result of magmatic/metamorphic events in the area (Kane and Kammerling, 1992) (figure 2). Mogok has been mined for gemstones from both primary deposits (underground and open pits) and secondary deposits (in alluvial and eluvial placers).

The Pyaung-Gaung peridot mining area is located approximately $10 \mathrm{~km}$ north-northwest of the town of
Mogok (again, see figure 2) and situated on a ridge along Taung Me Mountain, the highest mountain in the Mogok metamorphic complex, underlain by large granitic intrusives of biotite microgranite (Kabaing) (Iyer, 1953; Harlow and Thu, 2014; Sripoonjan et al., 2017). Kyaw Thu (2007) suggested that the Kabaing granite intruded into the peridotite at Pyaung-Gaung, 

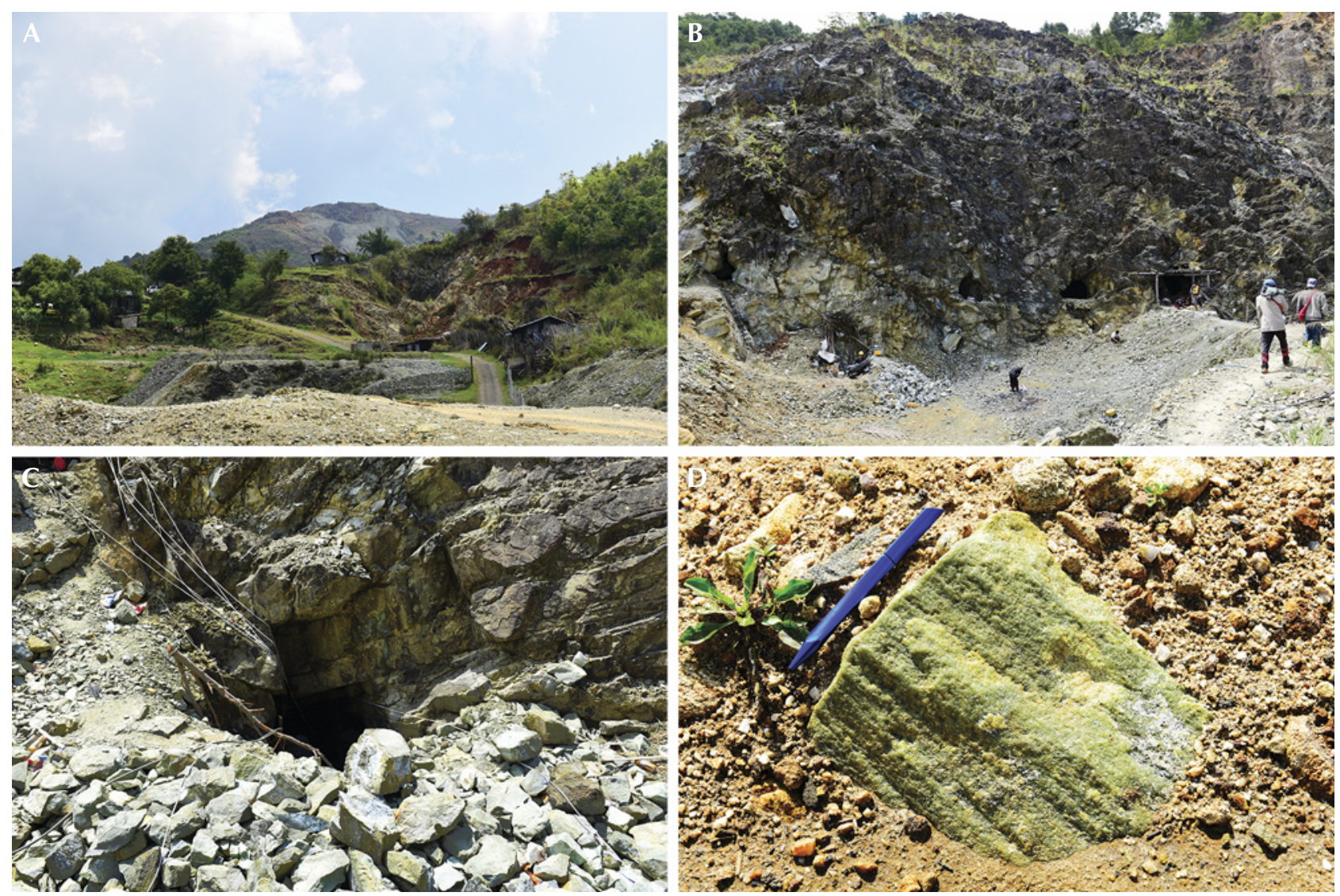

Figure 3. A: Mountains in the Pyaung-Gaung area. B: A mining site at the primary deposit in Pyaung-Gaung. C: A pit dug into the peridot-rich area of the peridotitic host rock. D: Serpentinized fine-grained dunite, the precursor host rock of gem-quality peridot, was abundant around the mine. Photos by T. Sripoonjan.

indicating the possible emplacement of ultramafic rocks during the early Jurassic and generally earlier than the Mogok Metamorphic Belt. However, peridot from Pyaung-Gaung is derived from ultramafic rocks that occurred as a layered intrusion in the associated garnet-biotite gneiss (Kabe). The area has been mined mainly for fine-quality peridot in the outcrops of precursor dunite, an olivine-dominant variety of peridotite, as this rock was commonly present around the mine area. Nevertheless, well-formed crystals are usually found in veinlets and pockets within fine-grained serpentinized peridotites (Kyaw Thu, 2007), partly due to recrystallization of olivine in tension gashes or tectonic fractures during lateral displacement and uplift along the Momeik fault (Lin, 2014; Bouilhol et al., 2015; Thu and Harlow, 2017) (figure 3).

Traditional mining methods are used at the Pyaung-Gaung peridot deposits. The rock along the hillside is drilled with a jackhammer and blasted off with dynamite. This results in an extensive network of tunnels, generally 3-5 m wide and extending inward or downward to more than $50 \mathrm{~m}$ deep. Within the tunnels, the miners use a pneumatic hammer or primitive tools such as hammer and chisel to extract peridot embedded in the partially serpentinized dunite host rock along the tunnel walls. An electric generator is used for lighting and power tools (figure 4). A mine cart and rope system transports the mined material and equipment out from the tunnels. For safety reasons, we were not allowed to see the in situ samples after the fresh exposure of rock was cut open. However, the rough peridot is typically extracted and collected from the mines, followed by cleaning, cutting, and polishing locally in the town of Mogok before entering the gem markets.

\section{MATERIALS AND METHODS}

Samples. All together, 33 peridot samples from the Pyaung-Gaung area were collected and used for this study. These consisted of five faceted stones weighing from 5.18-7.52 ct each (again, see figure 1) and 28 pieces of rough stones from 1.78-29.02 ct each (figure $5)$. The rough stones were divided into two groups: 

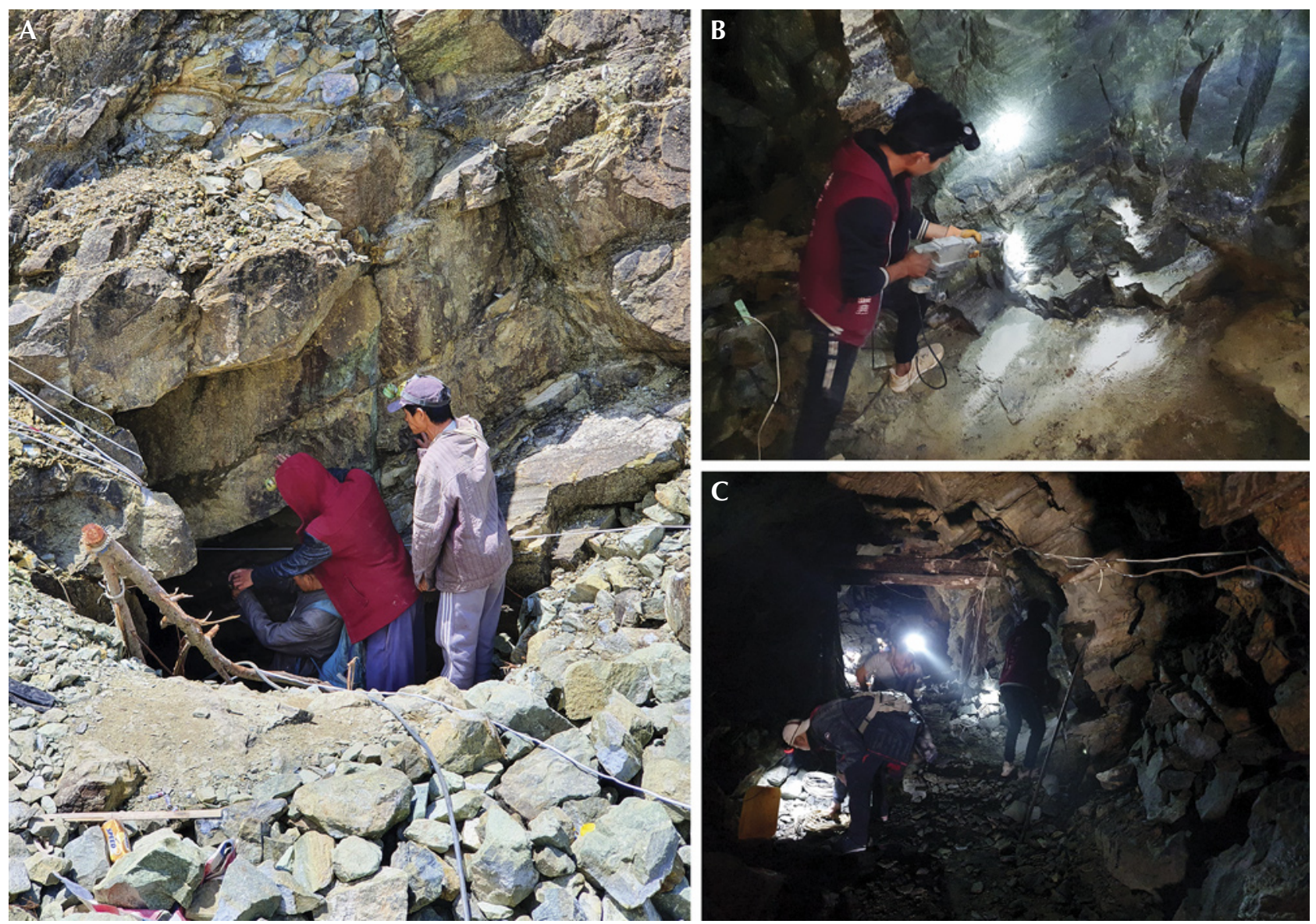

Figure 4. A: Miners entering the tunnel of an underground mine at the Pyaung-Gaung peridot deposits. B: A miner drills the rock along the tunnel wall with a pneumatic hammer to extract the peridot samples. C: Miners working in the main tunnel. Photos by M. Seneewong-Na-Ayutthaya (A) and T. Sripoonjan (B and C).

10 larger stones purchased directly from a local miner and 18 smaller ones from a reliable supplier in the town of Mogok. All faceted stones and larger rough stones had a rich olive green color; the smaller ones were yellowish green. All of the rough stones were cut and polished with a Facetron faceting ma-

Figure 5. The 28 Pyaung-Gaung peridot rough samples, 1.78-29.02 ct, collected and examined for this study. Photo by T. Sripoonjan.

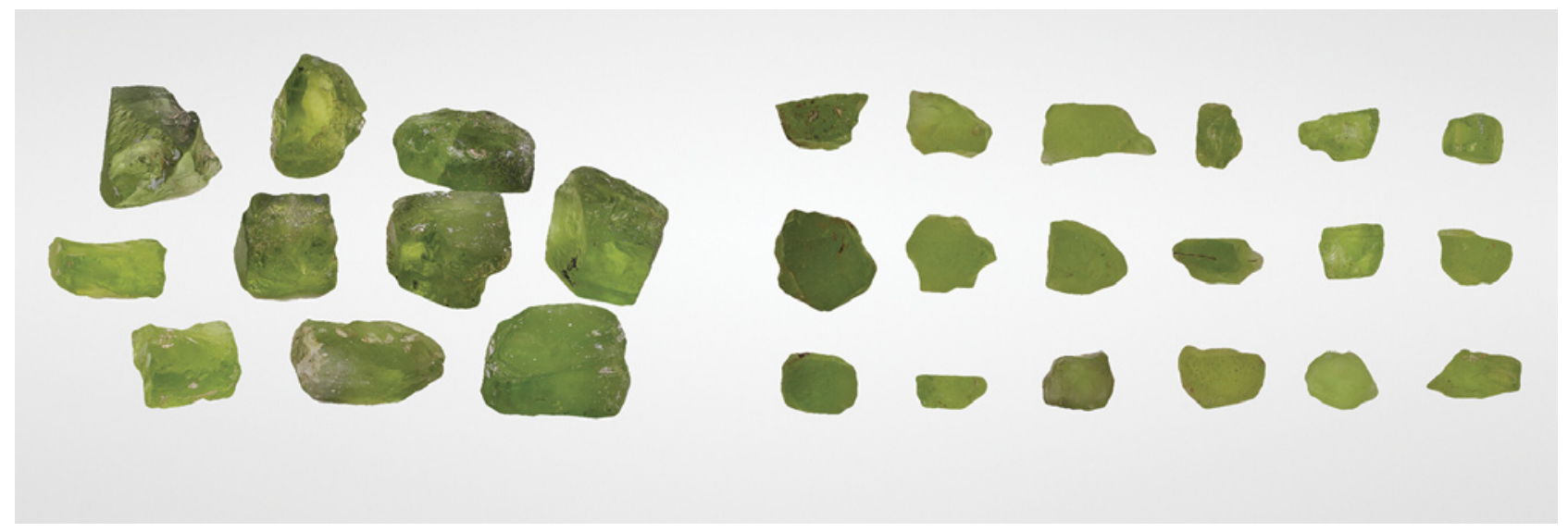


chine to have two parallel windows (regardless of orientation) for gemological and spectroscopic investigation. Standard gemological instruments were used to measure refractive indices (RIs), specific gravity (SG), pleochroism, and fluorescence reaction to longwave $(\sim 365 \mathrm{~nm})$ and short-wave $(254 \mathrm{~nm})$ ultraviolet lamps. In addition, this study used GIT-GTL peridot reference samples for elemental comparison and discrimination. These reference samples comprised 15 Pakistani peridots obtained from highly trusted traders from Pakistan and 26 Chinese peridots provided directly by Yanbian Fuli Olivine Mining Co., Ltd. of China. The GIT-GTL reference samples all ranged in size from 1.60 to $9.80 \mathrm{ct}$.

Microscopic Analysis and Spectroscopy. Internal features and photomicrographs were observed at $10 x-$ $75 \times$ magnification with a Zeiss Stemi 508 standard binocular gemological microscope attached to a Canon EOS 5D Mark III digital camera. Incident, darkfield, reflected, and oblique illumination techniques were employed to investigate internal characteristics. A polarizing filter was used to reduce the doubling effect from the birefringence of peridot.

A Renishaw inVia Raman microscope with a 532 $\mathrm{nm}$ laser was used for identifying mineral inclusions in the samples. Raman spectra were collected in the range of $1500-200 \mathrm{~cm}^{-1}$. The laser output power was 45 watts, and the spot size was $1.5 \mu \mathrm{m}$. The exposure time per scan was $10 \mathrm{~s}$. The mineral inclusions were identified and compared with the RRUFF and Renishaw mineral databases through Thermo Scientific's Spectral ID software. Unoriented ultraviolet/visible/near-infrared (UV-Vis-NIR) spectra were collected from 350 to $1500 \mathrm{~nm}$ with a PerkinElmer Lambda 1050 spectrophotometer using a data interval of $3 \mathrm{~nm}$ and a scan speed of 405.07 $\mathrm{nm} / \mathrm{min}$ operating with a 150 integrating sphere accessory. Fourier-transform infrared spectroscopy (FTIR) was carried out using Thermo Scientific Nicolet iN10 FTIR microscope (mid-IR spectra, $1200-500 \mathrm{~cm}^{-1}$ ) in reflection mode at $4 \mathrm{~cm}^{-1}$ resolution and 128 scans.

Chemical Analysis. Quantitative chemical composition was analyzed by an electron probe micro-analyzer (EPMA), JEOL model JXA-8100. The analyses were carried out with an accelerating voltage of $15 \mathrm{kV}$ and beam current of $25 \mathrm{nA}$, using a focused beam (smaller than $1 \mu \mathrm{m})$. Measurement times were set at $10 \mathrm{~s}$ for both the peak and background counts of all analyzed elements, leading to an empirical detection limit of
TABLE 1. Summary of gemological properties of peridot from Pyaung-Gaung, Mogok.

\begin{tabular}{c|c}
\hline Properties & Observation data \\
\hline Color & $\begin{array}{c}\text { Rich olive green (faceted stones and } \\
\text { larger rough samples) and yellowish } \\
\text { green (smaller rough samples) } \\
\text { Diaphaneity } \\
\text { Transparent } \\
\text { RI } \\
\text { Birefringence } \\
\text { SG } \\
\text { Pleochroism } \\
\text { O.648-1.689-0.041 } \\
\text { 3.24-3.36 } \\
\text { Weak to moderate: green and } \\
\text { yellowish green } \\
\text { Inert to long-wave and short-wave } \\
\text { UV radiation }\end{array}$ \\
\hline
\end{tabular}

about 0.005 wt.\%. For quantitative analyses, most of the standards used for calibration were pure oxide and mineral standards, including quartz for $\mathrm{Si}$, periclase for $\mathrm{Mg}$, manganosite for $\mathrm{Mn}$, nickel oxide for $\mathrm{Ni}$, fayalite for $\mathrm{Fe}$, and wollastonite for $\mathrm{Ca}$.

Laser ablation-inductively coupled plasma-mass spectrometry (LA-ICP-MS) was applied to analyze the trace element concentrations, using a Thermo Scientific iCAP RQ series ICP-MS coupled with an Elemental Scientific Lasers NWR-213 Nd:YAG laser ablation system. The laser employed a $10 \mathrm{~Hz}$ pulse rate and $55 \mu \mathrm{m}$ diameter spot size. The energy density was about $9 \mathrm{~J} / \mathrm{cm}^{2}$. Ablation was carried out in a He atmosphere, and the sample gas was mixed with Ar before entering the plasma. The gas background for pre-ablation was measured for $30 \mathrm{~s}$ to remove surface contamination, followed by a measurement time of $60 \mathrm{~s}$ and an elapsed interval time of $30 \mathrm{~s}$. NIST-SRM 610 and 612 glasses reference materials were used as the external calibration standards (Jochum et al., 2011). Data reduction was carried out using Thermo Scientific's Qtegra Intelligent Scientific Data Solution software to analyze the following elements: $\mathrm{Li}, \mathrm{Be}, \mathrm{B}, \mathrm{Na}, \mathrm{Mg}, \mathrm{Al}, \mathrm{Sc}, \mathrm{Ti}, \mathrm{V}, \mathrm{Cr}, \mathrm{Mn}, \mathrm{Co}$, $\mathrm{Ni}, \mathrm{Cu}, \mathrm{Zn}, \mathrm{Rb}, \mathrm{Sr}, \mathrm{Y}, \mathrm{Zr}, \mathrm{Nb}, \mathrm{Cs}, \mathrm{Ba}, \mathrm{Hf}, \mathrm{Ta}, \mathrm{Th}, \mathrm{U}$ $\mathrm{Pb}$, and the rare-earth elements from $\mathrm{La}$ to $\mathrm{Lu}$.

\section{RESULTS AND DISCUSSION}

Gemological Properties. The gemological properties of the 33 studied stones are summarized in table 1. Again, the colors were rich olive green for the faceted and larger rough samples and yellowish green for the smaller samples. All of the samples were transparent. RI and birefringence values fell in the range of 1.648- 

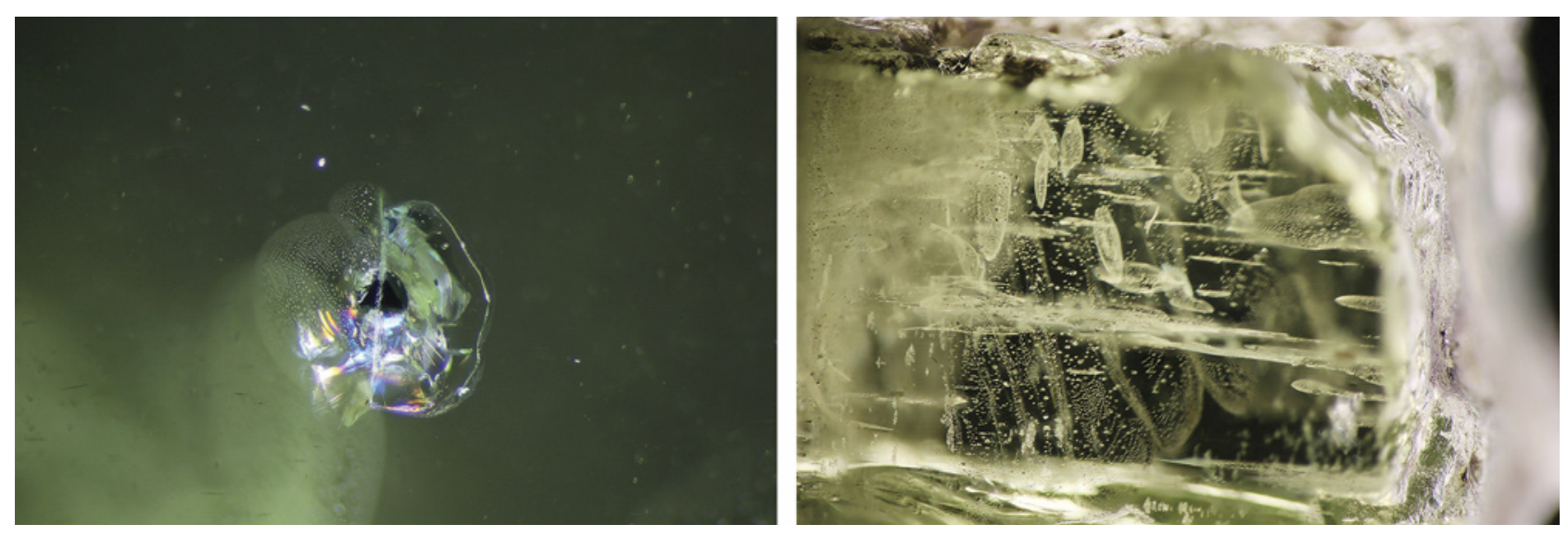

Figure 6. Internal features of Pyaung-Gaung peridot. Left: A typical lily pad inclusion with a black chromite crystal in the center surrounded by a decrepitation halo; field of view $2.8 \mathrm{~mm}$. Right: Typical discoid fissures around tiny inclusions; field of view $5.6 \mathrm{~mm}$. Photomicrographs by M. Seneewong-Na-Ayutthaya.

1.689 and $0.030-0.041$, respectively. SG varied between 3.24 and 3.36. The samples showed weak to moderate pleochroism in green and yellowish green. All were inert to both long-wave and short-wave UV radiation.

Microscopic Characteristics. One of the most common inclusions of the Pyaung-Gaung peridot was the so-called lily pad (figure 6). These are round to ovalshaped decrepitation halos surrounding dark chromite or other mineral inclusions.

Other common inclusions were opaque black octahedral chromite crystals, sometimes containing tension fractures oriented in three dimensions (figure 7), similar to those previously noted in peridot from the United States and China (Koivula, 1981; Koivula and Fryer, 1986; Sripoonjan et al., 2019; Zhang et al., 2019).

Moreover, most of the samples contained abundant small olivine inclusions that have not been reported in peridot from other locations (figure 8). Some olivine crystals were surrounded by partially healed fissures (figure 8, A and B). One of the included crystals was cut open on the surface of the host peridot and identified by Raman spectroscopy and subsequent EPMA and LA-ICP-MS analyses (see figure 15 and the Chemical Composition section below).

Careful observation showed that the external shapes of the olivine inclusions were partly resorbed, probably due to the change of environment during the host's crystallization (Harlow and Thu, 2014; Patil et al., 2017; Thu and Harlow, 2017). As such,

Figure 7. Internal features of Pyaung-Gaung peridot. Left: A dark octahedral chromite crystal; field of view 1.8 $\mathrm{mm}$. Right: An isolated octahedral chromite crystal surrounded by tension fractures; field of view $2.2 \mathrm{~mm}$. Photomicrographs by M. Seneewong-Na-Ayutthaya.
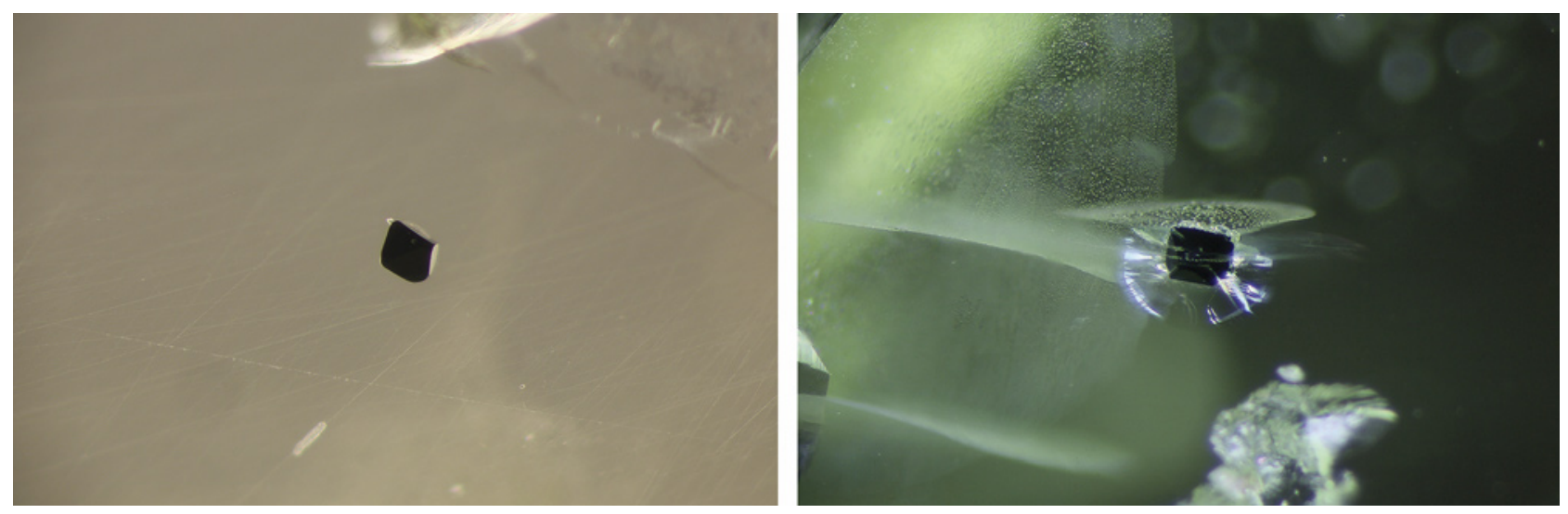

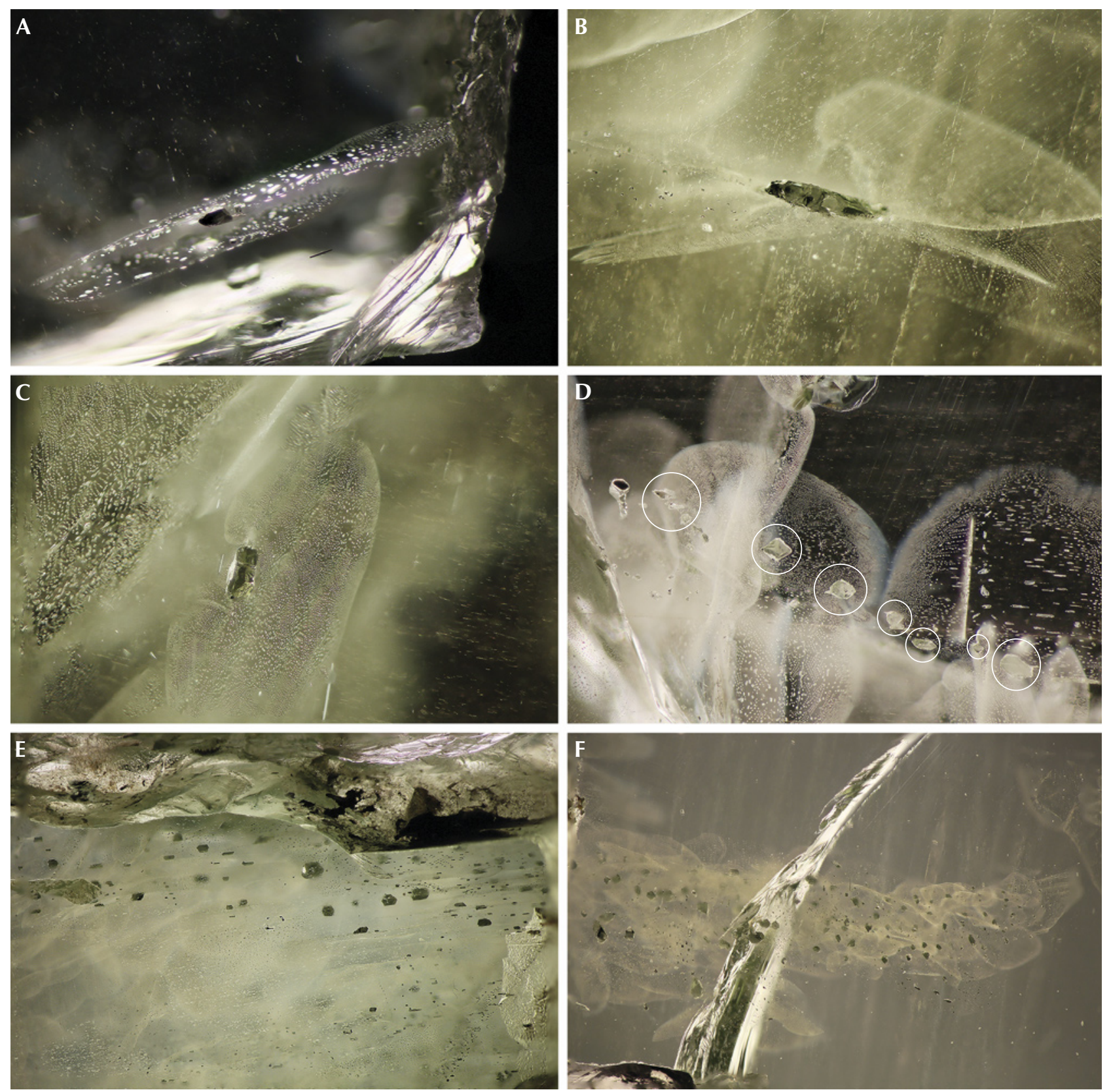

Figure 8. Internal features of Pyaung-Gaung peridot. A and B: An olivine crystal surrounded by partially healed fractures in a peridot host; field of view $3.8 \mathrm{~mm}$. C-E: Olivine crystal inclusions in a peridot host; field of view $7.5 \mathrm{~mm}$. F: Cluster of olivine crystals with wispy or smoky veils along with partially healed fractures; field of view $7.5 \mathrm{~mm}$. Photomicrographs by M. Seneewong-Na-Ayutthaya.

these olivine inclusions could be crystals from an earlier generation incorporated into the peridot host, making them "protogenetic" inclusions (Gübelin and Koivula, 2005). These protogenetic olivine inclusions may be considered a diagnostic characteristic of Pyaung-Gaung peridot.
Some solid inclusions occasionally found in these samples appeared to be biotite-phlogopite micas (figure 9A) and rutile (figure 9B), as well as secondary magnesite, serpentine, and talc (figure 9C). In addition, an inclusion assemblage of chromite, secondary magnesite, and chlorite surrounded by white serpen- 

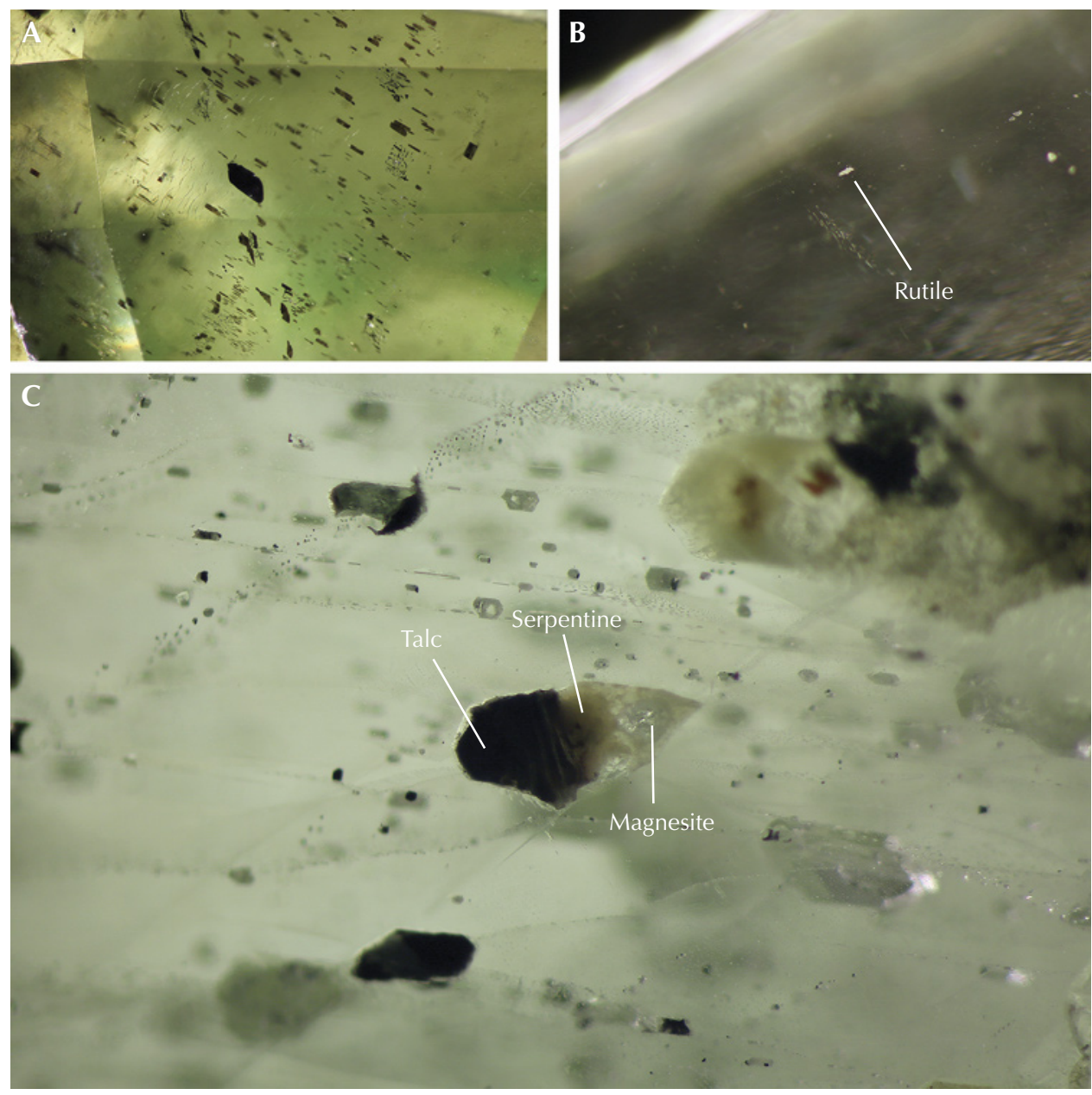

Figure 9. Internal features of Pyaung-Gaung peridot. A: Unidentified flat crystals (probably phlogopite-biotite micas) of various sizes; field of view $3.8 \mathrm{~mm}$. B: $A$ rutile inclusion; field of view $1.8 \mathrm{~mm}$. C: Inclusions of magnesite, serpentine, and talc the inclusion in the center was cut open and identified by Raman spectroscopy); field of view $2.2 \mathrm{~mm}$. Photomicrographs by $M$. Seneewong-Na-Ayutthaya.

tine was found in one sample (figure 10). Except for the biotite-phlogopite micas, all were identified by Raman spectroscopy.

Chromite is often found within olivine-rich cumulates and occurs as small grains in ultramafic rock associated with serpentine, talc, and magnesite (Barnes, 1998; Salem et al., 2012). Some metamorphisms can also produce predominantly chlorite in association with talc (Sharp and Buseck, 1988). The presence of serpentine is commonly referred to as a hydration reaction (serpentinization) that occurred when olivine was infiltrated by aqueous fluids, while talc and magnesite were produced through a carbonation reaction when carbon dioxide $\left(\mathrm{CO}_{2}\right)$ was present (Kelemen and Hirth, 2012; Lafay et al., 2018). The combined hydration and carbonation processes could be an indication of retrograde alteration in these Mogok peridot as the result of tectonic movements (Jan and Khan, 1996; Kelemen and Hirth, 2012; Bouilhol et al., 2015; Tzamos et al., 2020).

In faceted samples, low magnification commonly revealed unidentified tufts of very fine fibers (proba- bly chrysotile; G. Harlow, pers. comm., 2021) that resembled black needles (figure 11).

Healed fissures (figure 12, A-C) and fluid-like inclusions (figure 12D) were regularly present and exhibited wide variation in appearance. Burmese peridot, as a product of partial metamorphism, has undergone recurring inner damage during the growth process. As a result, healing fissures and fluid-like inclusions formed within it from the process of continuous repair in the crystal itself during the recrystallization process (Gübelin and Koivula, 2004). Unfortunately, these inclusions could not be identified by Raman spectroscopy. Also observed in the Pyaung-Guang peridot were needle-like inclusions (figure 12E) showing an iridescent effect in reflected light.

Spectroscopy. UV-Vis-NIR Spectra. The UV-Vis-NIR absorption spectra of the Pyaung-Gaung peridot samples all showed similar patterns, as illustrated in figure 13. The absorption coefficient $(\alpha)$ was calculated from the true absorbance in an uncorrected ab- 


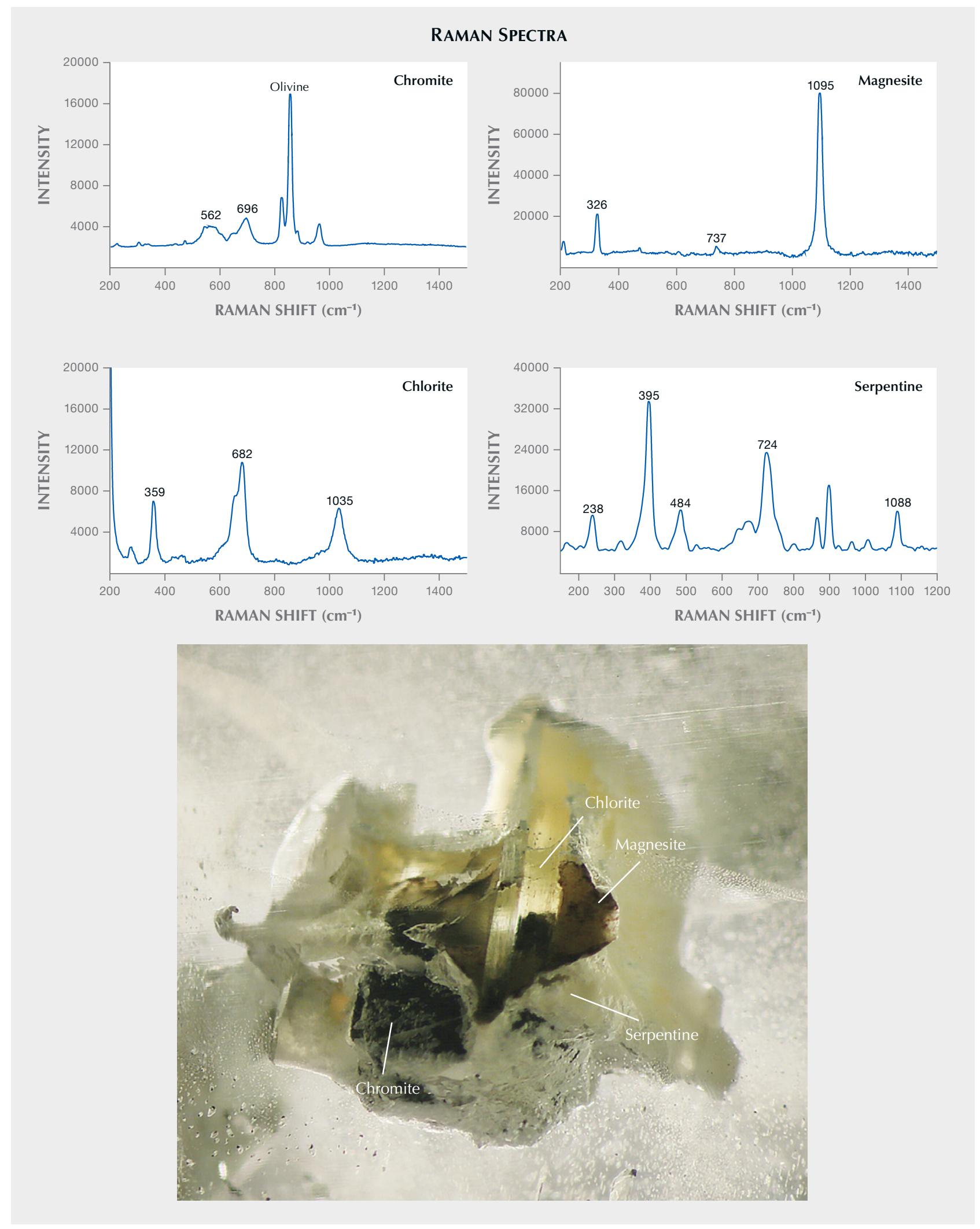

Figure 10. An assemblage of mineral inclusions comprising chromite, magnesite, and chlorite, surrounded in part by serpentine; field of view $5.6 \mathrm{~mm}$. Their Raman spectra were used to prove the mineral species. Photomicrograph by M. Seneewong-Na-Ayutthaya. 

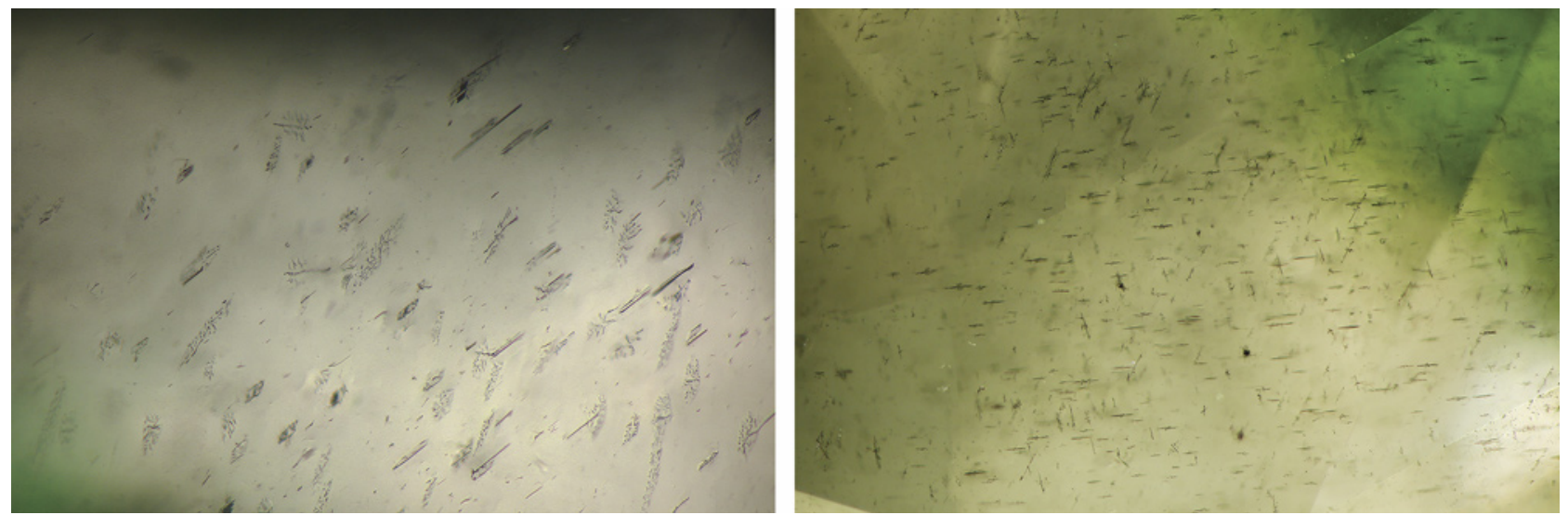

Figure 11. Tufts of very fine fibers (probably chrysotile) in a Pyaung-Gaung peridot; fields of view $1.8 \mathrm{~mm}$ (left) and $3.8 \mathrm{~mm}$ (right). Photomicrographs by M. Seneewong-Na-Ayutthaya.

sorbance $(A)$ and the thickness $(t)$ of the sample in centimeters, according to the equation below (Dubinsky et al., 2020):

$$
\alpha=2.303 \mathrm{~A} / \mathrm{t}
$$

The figure 13 spectrum displays a broad absorption band peak at $1050 \mathrm{~nm}$, a shoulder at about $864 \mathrm{~nm}$ in the near IR, and additional weak bands at 381, 402, 453,495 , and $633 \mathrm{~nm}$. The gradual increase in ab-
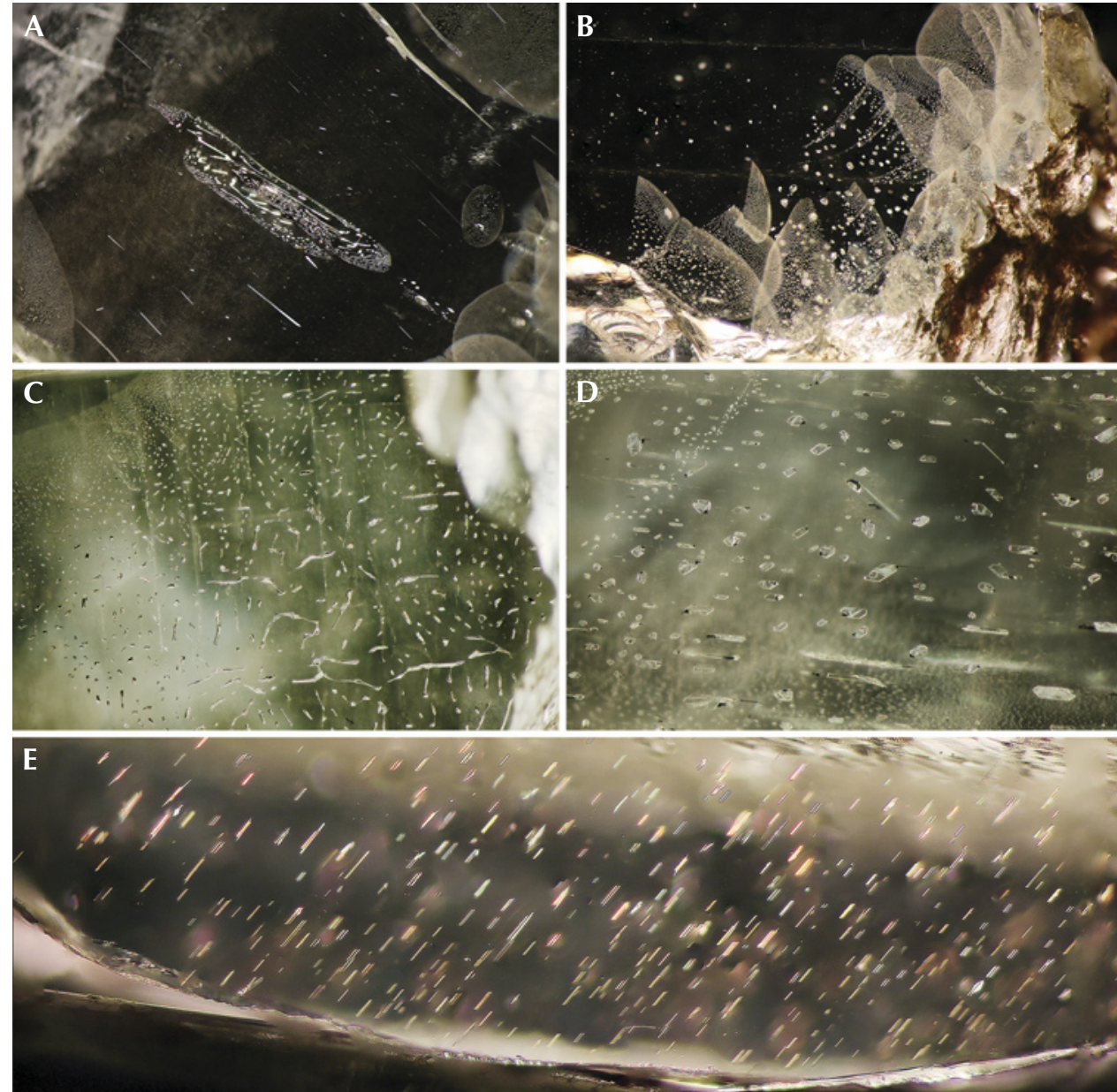

Figure 12. Internal features of Pyaung-Gaung peridot. A: A tiny crystal surrounded by superimposed partially healed fractures; field of view $9.0 \mathrm{~mm}$. B: Partially healed fissures showing a fingerprintlike attribute; field of view $5.6 \mathrm{~mm}$. C: A typical healed fracture; field of view $4.5 \mathrm{~mm}$. D: Fluid-like inclusions; field of view 1.8 mm. E: Needle-like inclusions with an iridescent effect; field of view $2.8 \mathrm{~mm}$. Photomicrographs by $M$. Seneewong-Na-Ayutthaya. 


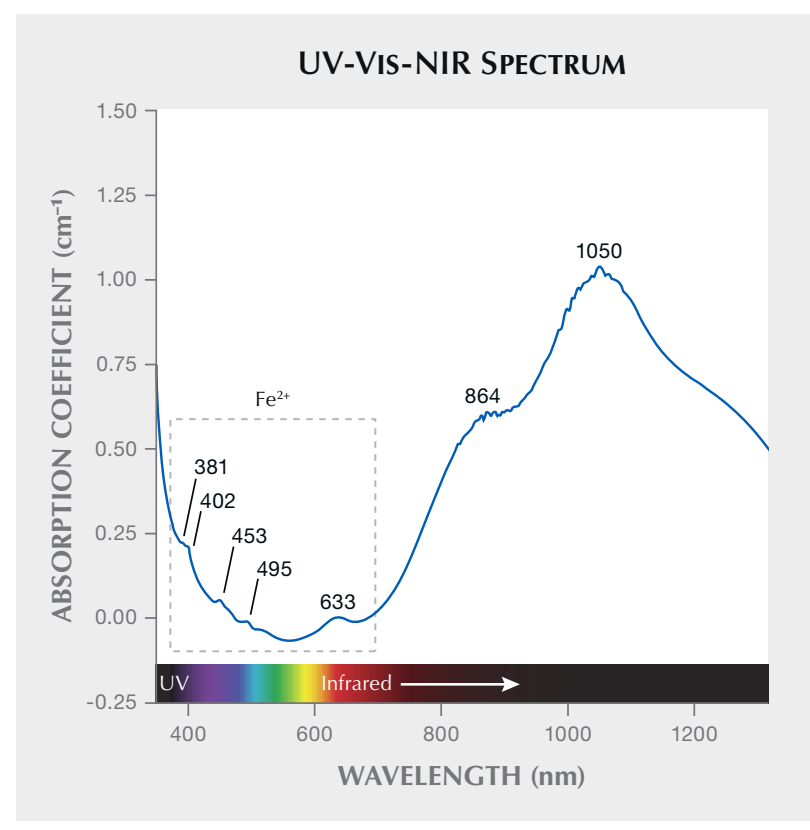

Figure 13. This representative non-polarized UV-VisNIR spectrum of Pyaung-Gaung peridot is characterized mainly by $\mathrm{Fe}^{2+}$ absorption features.

sorption from the visible to the UV region allows a broad transmission window minimum at around 560 $\mathrm{nm}$, giving rise to the green coloration of the stone. The absorption feature of this Burmese peridot is usually attributed to $\mathrm{Fe}^{2+}$, which is a main chromophore contributing to the green color. This spec-

Figure 14. A representative FTIR spectrum obtained from a Pyaung-Gaung peridot. All the marked absorption bands are related to internal Si-O vibrations (Burns and Huggins, 1972).

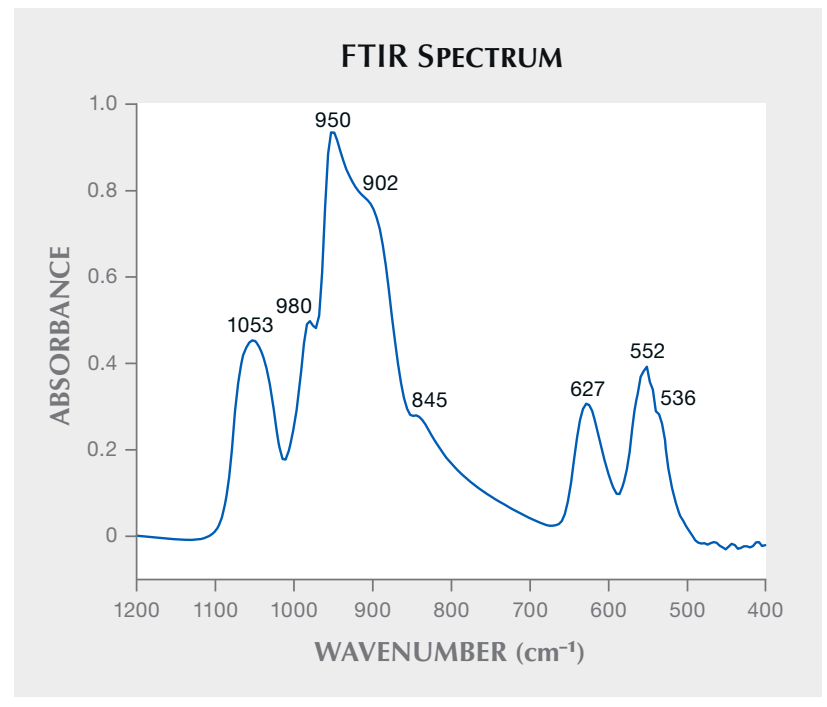

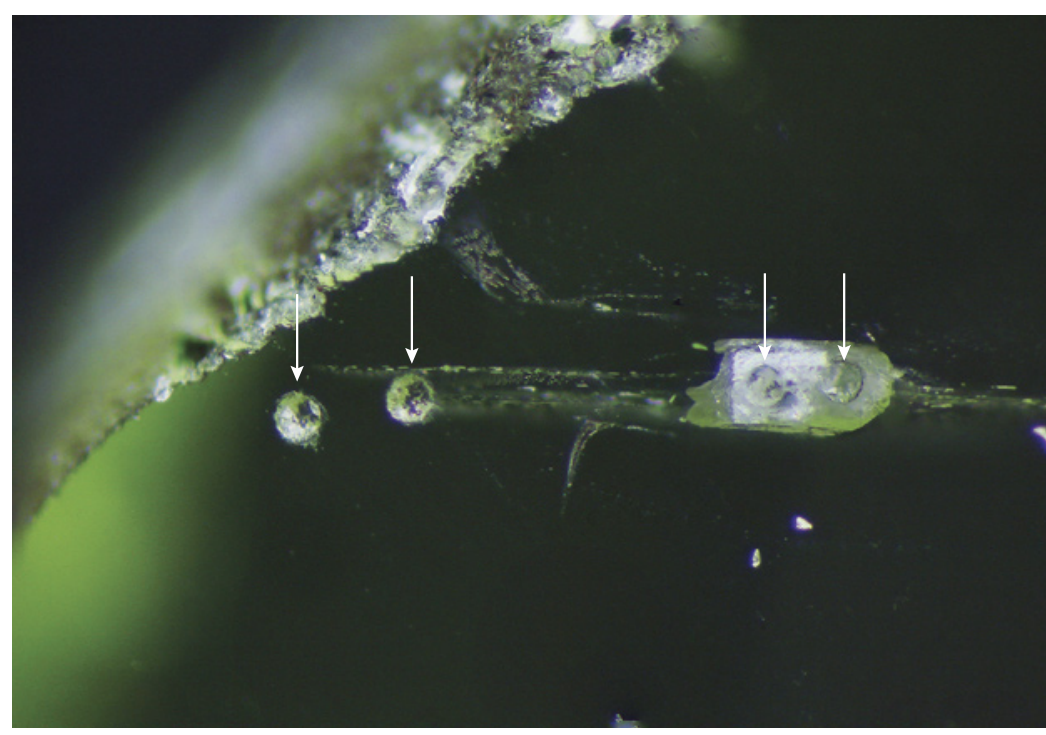

Figure 15. Laser spots (marked by arrows) show where an olivine inclusion and the peridot host were analyzed by LA-ICP-MS. Photomicrograph by M. Seneewong-Na-Ayuthaya; field of view $1.8 \mathrm{~mm}$.

troscopic feature is also observed in peridot from other localities (e.g., Adamo et al., 2009; Thuyet et al., 2016; Sripoonjan et al., 2019).

FTIR Spectra. A representative FTIR spectrum of the Pyaung-Gaung peridot samples is shown in figure 14. Characteristic mid-IR spectra revealed several absorption bands located at 1053, 980, 950, 902, $845,627,552$, and $536 \mathrm{~cm}^{-1}$. These bands were assigned to internal Si-O vibrations (Burns and Huggins, 1972). Although the IR patterns are quite similar to those of Sardinian peridot (reported in Adamo et al., 2009), the maxima positions of all IR bands can be shifted to either lower or higher frequency values depending on the content of iron $\left(\mathrm{Fe}^{2+}\right)$, as previously suggested by Duke and Stephens (1964), Burns and Huggins (1972), and Jovanovski et al. (2006).

Chemical Compositions. Olivine Inclusion. To understand the chemical relationship between the olivine inclusion and the host crystal, major element (by EPMA) and trace element concentrations (by LAICP-MS) of a cut-open inclusion and nearby host crystal were analyzed (see figure 15). The results, presented in table 2, showed that the major contents of $\mathrm{SiO}_{2}, \mathrm{MgO}, \mathrm{CaO}, \mathrm{FeO}, \mathrm{MnO}$, and $\mathrm{NiO}$ and trace contents of $\mathrm{Li}, \mathrm{B}, \mathrm{Na}, \mathrm{Al}, \mathrm{Sc}, \mathrm{Ti}, \mathrm{V}, \mathrm{Cr}, \mathrm{Mn}, \mathrm{Co}, \mathrm{Ni}, \mathrm{Zn}$, $\mathrm{Ge}$, and $\mathrm{Zr}$ of the inclusion and the host are relatively similar. 
TABLE 2. Contents of major elements (by EPMA) and trace elements (by LA-ICP-MS) of the host peridot sample and the olivine inclusion (average and range).

\begin{tabular}{|c|c|c|c|}
\hline Chemical composition & Host peridot & Olivine inclusion & Detection limit \\
\hline \multicolumn{4}{|c|}{ Major contents (wt.\%) of two spot analyses by EPMA } \\
\hline $\mathrm{SiO}_{2}$ & $\begin{array}{c}42.77 \\
(42.56-42.98)\end{array}$ & $\begin{array}{c}42.85 \\
(41.92-43.78)\end{array}$ & 0.005 \\
\hline $\mathrm{MgO}$ & $\begin{array}{c}49.23 \\
(48.49-49.97)\end{array}$ & $\begin{array}{c}50.55 \\
(49.25-51.85)\end{array}$ & 0.005 \\
\hline $\mathrm{FeO}$ & $\begin{array}{c}7.61 \\
(7.35-7.87)\end{array}$ & $\begin{array}{c}7.25 \\
(6.64-7.86)\end{array}$ & 0.005 \\
\hline $\mathrm{MnO}$ & $\begin{array}{c}0.04 \\
(0.01-0.07)\end{array}$ & $\begin{array}{c}0.04 \\
(0.02-0.06)\end{array}$ & 0.005 \\
\hline $\mathrm{NiO}$ & $\begin{array}{c}0.34 \\
(0.16-0.52)\end{array}$ & $\begin{array}{c}0.01 \\
(0.01-0.01)\end{array}$ & 0.005 \\
\hline $\mathrm{CaO}$ & $\begin{array}{c}0.02 \\
(0.01-0.03)\end{array}$ & $\begin{array}{c}0.02 \\
(0.01-0.02)\end{array}$ & 0.005 \\
\hline Total & $\begin{array}{c}100.01 \\
(100.01-100.1)\end{array}$ & $\begin{array}{c}100.71 \\
(99.12-102.31)\end{array}$ & \\
\hline \multicolumn{4}{|c|}{ Trace contents (ppmw) of two spot analyses by LA-ICP-MS } \\
\hline $\mathrm{Li}$ & $\begin{array}{c}3.33 \\
(3.10-3.56)\end{array}$ & $\begin{array}{c}2.31 \\
(0.41-4.22)\end{array}$ & 0.05 \\
\hline B & $\begin{array}{c}7.34 \\
(3.26-11.42)\end{array}$ & $\begin{array}{c}13.75 \\
(13.25-14.25)\end{array}$ & 0.45 \\
\hline $\mathrm{Na}$ & $\begin{array}{c}7.63 \\
\text { (bdl-15.25) }\end{array}$ & $\begin{array}{c}33.56 \\
(31.49-35.54)\end{array}$ & 9.45 \\
\hline $\mathrm{Al}$ & $\begin{array}{c}7.23 \\
(5.56-8.82)\end{array}$ & $\begin{array}{c}5.08 \\
(1.88-8.29)\end{array}$ & 0.66 \\
\hline Sc & $\begin{array}{c}5.95 \\
(5.64-6.26)\end{array}$ & $\begin{array}{c}5.14 \\
(5.09-5.19)\end{array}$ & 0.08 \\
\hline $\mathrm{Ti}$ & $\begin{array}{c}3.33 \\
(1.54-5.13)\end{array}$ & $\begin{array}{c}8.62 \\
\left(b_{d}{ }^{a}-17.23\right)\end{array}$ & 1.90 \\
\hline V & $\begin{array}{c}0.29 \\
\text { (bdl-0.58) }\end{array}$ & $\begin{array}{c}0.31 \\
(0.09-0.53)\end{array}$ & 0.08 \\
\hline $\mathrm{Cr}$ & $\begin{array}{c}14.02 \\
(5.14-22.90)\end{array}$ & $\begin{array}{c}6.73 \\
(6.61-6.86)\end{array}$ & 0.36 \\
\hline $\mathrm{Mn}$ & $\begin{array}{c}852.11 \\
(841.21-863.01)\end{array}$ & $\begin{array}{c}1018.50 \\
(866.59-1170.40)\end{array}$ & 0.05 \\
\hline Co & $\begin{array}{c}148.81 \\
(145.56-152.06)\end{array}$ & $\begin{array}{c}150.15 \\
(142.17-158.13)\end{array}$ & 0.07 \\
\hline $\mathrm{Ni}$ & $\begin{array}{c}3775.53 \\
(3733.27-3817.78)\end{array}$ & $\begin{array}{c}3481.55 \\
(3449.87-3513.22)\end{array}$ & 0.08 \\
\hline $\mathrm{Zn}$ & $\begin{array}{c}42.14 \\
(41.07-43.21)\end{array}$ & $\begin{array}{c}57.32 \\
(48.33-66.30)\end{array}$ & 0.01 \\
\hline $\mathrm{Ge}$ & $\begin{array}{c}2.75 \\
(1.49-4.02)\end{array}$ & $\begin{array}{c}0.70 \\
\text { (bdl-1.39) }\end{array}$ & 0.30 \\
\hline $\mathrm{Zr}$ & $\begin{array}{c}0.05 \\
(0.03-0.07)\end{array}$ & $\begin{array}{c}0.02 \\
\text { (bdl-0.05) }\end{array}$ & 0.01 \\
\hline
\end{tabular}


TABLE 3. Chemical composition of peridot samples from Pyaung-Gaung and other localities by EPMA ${ }^{a}$ (average and range).

\begin{tabular}{|c|c|c|c|}
\hline Chemical composition & $\begin{array}{c}\text { Pyaung-Gaung, } \\
\text { Myanmar } \\
\text { (33 samples) }\end{array}$ & $\begin{array}{l}\text { Yiqisong, China } \\
\text { (26 samples) }\end{array}$ & $\begin{array}{c}\text { Sapat, Pakistan } \\
\text { (15 samples) }\end{array}$ \\
\hline \multicolumn{4}{|c|}{ Oxides (wt.\%) } \\
\hline $\mathrm{SiO}_{2}$ & $\begin{array}{c}42.62 \\
(41.90-43.20)\end{array}$ & $\begin{array}{c}40.94 \\
(40.30-42.48)\end{array}$ & $\begin{array}{c}42.58 \\
(42.03-43.13)\end{array}$ \\
\hline $\mathrm{MgO}$ & $\begin{array}{c}50.04 \\
(49.23-50.77)\end{array}$ & $\begin{array}{c}50.52 \\
(50.03-50.79)\end{array}$ & $\begin{array}{c}48.24 \\
(46.95-50.50)\end{array}$ \\
\hline $\mathrm{FeO}$ & $\begin{array}{c}7.64 \\
(7.25-7.88)\end{array}$ & $\begin{array}{c}8.42 \\
(7.69-9.05)\end{array}$ & $\begin{array}{c}8.32 \\
(6.57-9.58)\end{array}$ \\
\hline $\mathrm{MnO}$ & $\begin{array}{c}0.10 \\
(0.09-0.16)\end{array}$ & $\begin{array}{c}0.12 \\
(0.09-0.15)\end{array}$ & $\begin{array}{c}0.12 \\
(0.09-0.15)\end{array}$ \\
\hline $\mathrm{NiO}$ & $\begin{array}{c}0.15 \\
(0.02-0.34)\end{array}$ & $\begin{array}{c}0.06 \\
(0.02-0.14)\end{array}$ & $\begin{array}{c}0.12 \\
\left(\mathrm{bdl} \mathrm{l}^{\mathrm{b}}-0.32\right)\end{array}$ \\
\hline $\mathrm{CaO}$ & $\begin{array}{c}0.03 \\
\text { (bdl-0.12) }\end{array}$ & $\begin{array}{c}0.05 \\
\text { (bdl-0.16) }\end{array}$ & $\begin{array}{c}0.00 \\
\text { (bdl-0.02) }\end{array}$ \\
\hline Total & $\begin{array}{c}100.59 \\
(98.49-102.47)\end{array}$ & $\begin{array}{c}100.18 \\
(98.13-102.77)\end{array}$ & $\begin{array}{c}99.93 \\
(95.64-103.7)\end{array}$ \\
\hline \multicolumn{4}{|c|}{ Cations per 4 oxygen } \\
\hline $\mathrm{Si}$ & $\begin{array}{c}1.024 \\
(1.022-1.021)\end{array}$ & $\begin{array}{c}0.996 \\
(0.997-1.007)\end{array}$ & $\begin{array}{c}1.068 \\
(1.053-1.015)\end{array}$ \\
\hline $\mathrm{Mg}$ & $\begin{array}{c}1.793 \\
(1.791-1.789)\end{array}$ & $\begin{array}{c}1.832 \\
(1.796-1.845)\end{array}$ & $\begin{array}{c}1.804 \\
(1.772-1.754)\end{array}$ \\
\hline $\mathrm{Fe}$ & $\begin{array}{c}0.154 \\
(0.148-0.156)\end{array}$ & $\begin{array}{c}0.171 \\
(0.159-0.180)\end{array}$ & $\begin{array}{c}0.175 \\
(0.138-0.189)\end{array}$ \\
\hline $\mathrm{Mn}$ & $\begin{array}{c}0.002 \\
(0.002-0.003)\end{array}$ & $\begin{array}{c}0.002 \\
(0.002-0.003)\end{array}$ & $\begin{array}{c}0.003 \\
(0.002-0.003)\end{array}$ \\
\hline $\mathrm{Ni}$ & $\begin{array}{c}0.003 \\
(0.000-0.006)\end{array}$ & $\begin{array}{c}0.001 \\
(0.000-0.003)\end{array}$ & $\begin{array}{c}0.002 \\
(0.000-0.006)\end{array}$ \\
\hline $\mathrm{Ca}$ & $\begin{array}{c}0.001 \\
(0.000-0.003)\end{array}$ & $\begin{array}{c}0.001 \\
(0.000-0.004)\end{array}$ & $\begin{array}{c}0.000 \\
(0.000-0.001)\end{array}$ \\
\hline Sum & $\begin{array}{c}2.976 \\
(2.974-2.979)\end{array}$ & $\begin{array}{c}3.004 \\
(3.003-2.993)\end{array}$ & $\begin{array}{c}2.926 \\
(2.947-2.985)\end{array}$ \\
\hline $\mathrm{Mg} /(\mathrm{Mg}+\mathrm{Fe})$ & 0.921 & 0.915 & 0.912 \\
\hline $\mathrm{Mg} /\left(\sum \mathrm{M}^{2+}\right)$ & 0.918 & 0.913 & 0.909 \\
\hline
\end{tabular}

Major and Trace Elements. The compositions of major elements by EPMA and trace elements by LA-ICP-MS of the peridot samples from the three localities of Pyaung-Gaung, Yiqisong in China, and Sapat in Pakistan (GIT-GTL reference samples) are presented in tables 3 and 4, respectively. The chemical composition of Pyaung-Gaung peridot ranged from $92.00 \%$ to $92.37 \%$ forsterite $\left(\mathrm{Mg}_{2} \mathrm{SiO}_{4}\right)$ and $7.63 \%$ to $8.00 \%$ fay- alite $\left(\mathrm{Fe}_{2} \mathrm{SiO}_{4}\right)$, suggesting a mantle source. The composition of major elements was $50.04 \mathrm{wt} . \% \mathrm{MgO}$ and 42.62 wt. \% $\mathrm{SiO}_{2}$, averages similar to those of peridot from Yiqisong and Sapat. The $\mathrm{FeO}, \mathrm{MnO}, \mathrm{NiO}$, and $\mathrm{CaO}$ contents were nearly identical across the three localities. The average $\mathrm{MnO}$ and $\mathrm{NiO}$ contents were 0.10 wt. $\%$ and 0.15 wt. $\%$, respectively, indicating the olivine was from a mantle origin (Ishimaru and Arai, 
TABLE 4. Trace element concentrations of peridot samples from Pyaung-Gaung and other localities by LA-ICP-MS (average and range).

\begin{tabular}{|c|c|c|c|c|}
\hline $\begin{array}{c}\text { Chemical } \\
\text { composition }\end{array}$ & $\begin{array}{l}\text { Pyaung-Gaung, } \\
\text { Myanmar } \\
\text { (33 samples) }\end{array}$ & $\begin{array}{l}\text { Yiqisong, China } \\
\text { (26 samples) }\end{array}$ & $\begin{array}{l}\text { Sapat, Pakistan } \\
\text { (15 samples) }\end{array}$ & Detection limit \\
\hline \multicolumn{5}{|c|}{ Average trace element values (ppmw) } \\
\hline $\mathrm{Li}$ & $\begin{array}{c}4.59 \\
(1.45-15.77)\end{array}$ & $\begin{array}{c}3.18 \\
(1.58-9.99)\end{array}$ & $\begin{array}{c}4.43 \\
(1.46-9.25)\end{array}$ & 0.05 \\
\hline B & $\begin{array}{c}13.21 \\
(4.40-46.24)\end{array}$ & $\begin{array}{c}10.25 \\
(2.03-33.52)\end{array}$ & $\begin{array}{c}57.20 \\
(13.56-125.79)\end{array}$ & 0.45 \\
\hline $\mathrm{Na}$ & $\begin{array}{c}46.02 \\
(23.04-97.75)\end{array}$ & $\begin{array}{c}128.03 \\
(53.14-261.01)\end{array}$ & $\begin{array}{c}102.80 \\
(25.49-572.09)\end{array}$ & 9.45 \\
\hline $\mathrm{Al}$ & $\begin{array}{c}44.24 \\
(19.50-103.14)\end{array}$ & $\begin{array}{c}117.08 \\
(60.67-227.14)\end{array}$ & $\begin{array}{c}37.88 \\
(9.62-148.40)\end{array}$ & 0.66 \\
\hline Sc & $\begin{array}{c}11.52 \\
(8.19-15.92)\end{array}$ & $\begin{array}{c}10.33 \\
(8.09-12.39)\end{array}$ & $\begin{array}{c}23.84 \\
(8.25-46.50)\end{array}$ & 0.08 \\
\hline $\mathrm{Ti}$ & $\begin{array}{c}13.73 \\
(6.35-57.94)\end{array}$ & $\begin{array}{c}18.04 \\
(8.99-30.44)\end{array}$ & $\begin{array}{c}13.52 \\
(6.05-31.84)\end{array}$ & 1.90 \\
\hline V & $\begin{array}{c}1.88 \\
(1.01-7.69)\end{array}$ & $\begin{array}{c}3.64 \\
(2.15-8.11)\end{array}$ & $\begin{array}{c}1.58 \\
(0.52-6.05)\end{array}$ & 0.08 \\
\hline $\mathrm{Cr}$ & $\begin{array}{c}36.46 \\
(12.83-68.97)\end{array}$ & $\begin{array}{c}112.24 \\
(51.40-252.18)\end{array}$ & $\begin{array}{c}43.54 \\
(6.49-160.62)\end{array}$ & 0.36 \\
\hline $\mathrm{Mn}$ & $\begin{array}{c}914.16 \\
(788.54-1097.55)\end{array}$ & $\begin{array}{c}1017.62 \\
(850.90-1149.53)\end{array}$ & $\begin{array}{c}1214.88 \\
(1013.86-1424.91)\end{array}$ & 0.05 \\
\hline Co & $\begin{array}{c}142.67 \\
(123.46-167.77)\end{array}$ & $\begin{array}{c}151.19 \\
(132.14-170.41)\end{array}$ & $\begin{array}{c}154.92 \\
(134.56-178.57)\end{array}$ & 0.07 \\
\hline $\mathrm{Ni}$ & $\begin{array}{c}3371.39 \\
(2761.62-3965.21)\end{array}$ & $\begin{array}{c}3348.46 \\
(2964.32-3813.38)\end{array}$ & $\begin{array}{c}2036.65 \\
(1208.84-2675.79)\end{array}$ & 0.08 \\
\hline $\mathrm{Zn}$ & $\begin{array}{c}62.75 \\
(40.86-119.95)\end{array}$ & $\begin{array}{c}68.35 \\
(50.01-99.25)\end{array}$ & $\begin{array}{c}25.52 \\
(15.63-41.24)\end{array}$ & 0.01 \\
\hline $\mathrm{Ge}$ & $\begin{array}{c}2.82 \\
(0.44-5.77)\end{array}$ & $\begin{array}{c}3.57 \\
(2.36-7.77)\end{array}$ & $\begin{array}{c}4.10 \\
(2.14-8.04)\end{array}$ & 0.30 \\
\hline $\mathrm{Zr}$ & $\begin{array}{c}0.07 \\
(\mathrm{bdl}-0.99)\end{array}$ & $\begin{array}{c}0.03 \\
\text { (bdl-0.41) }\end{array}$ & $\begin{array}{c}0.07 \\
\text { (bdl-0.74) }\end{array}$ & 0.01 \\
\hline
\end{tabular}

2008). The atomic proportions were recalculated to present the ratios of $\mathrm{Mg} /(\mathrm{Mg}+\mathrm{Fe})$, for which all locations had a similar value.

The average trace element contents of peridot from the three origins, listed in table 4, show somewhat similar concentrations. Ni was the most abundant trace element, followed by $\mathrm{Mn}, \mathrm{Co}, \mathrm{Na}, \mathrm{Al}, \mathrm{Zn}$, $\mathrm{Cr}$, Sc, Ti, B, Li, Ge, V, and Zr. The Pyaung-Gaung peridot contained higher concentrations of $\mathrm{Ni}$ and $\mathrm{Zn}$ than the Sapat peridot but lower B, Na, Sc, and Mn. The Yiqisong peridot possessed higher $\mathrm{Na}, \mathrm{Al}$, and $\mathrm{Cr}$ contents than the Pyaung-Gaung samples. Previous studies showed that the formation of Yiqisong peridot was related to serpentinization (Zhang et al.,
2019) and/or spinel lherzolite that was quite similar to those of peridot from Sardinia and Vietnam (Adamo et al., 2009; Thuyet et al., 2016). In contrast, the study of Harlow and Thu (2014) indicated that samples from Pyaung-Gaung and Sapat shared a similar origin. The next section of this study reveals some differences in trace element concentration that are very helpful for geographic origin determination.

Origin Determination. The trace element data were then displayed and discriminated in 2D plots of $\mathrm{Al}-$ $\mathrm{Mn}, \mathrm{Cr}-\mathrm{Ni}$, Sc-Cr, Co-Mn, V-Ni, and V-Mn (figure 16) and $3 \mathrm{D}$ plots of Ni-Co-V, Ni-Ti-Cr, Ni-Ti-V, Cr-V-Sc, Co-V-Sc, and Cr-V-Co (figure 17). The 2D and 3D 


\section{D SCATTER PlOTS}

A

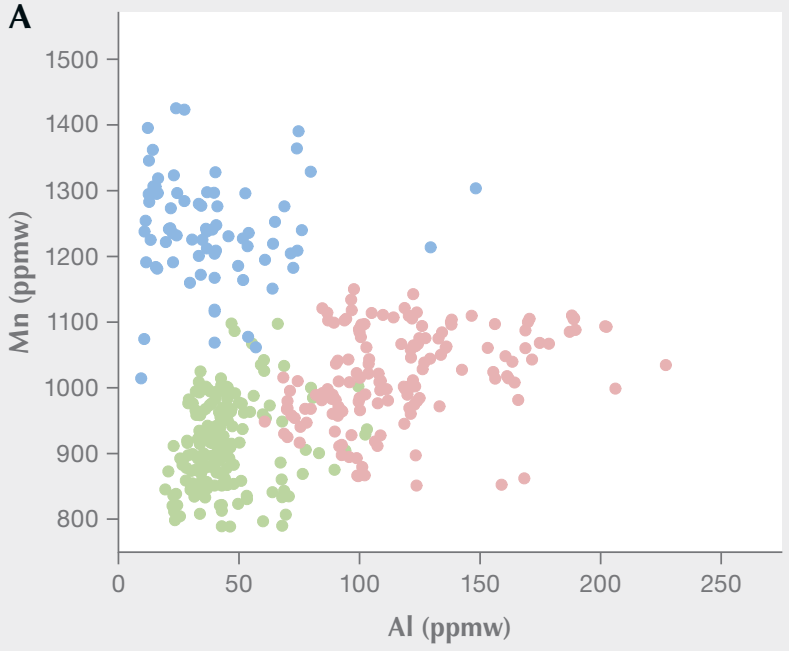

C

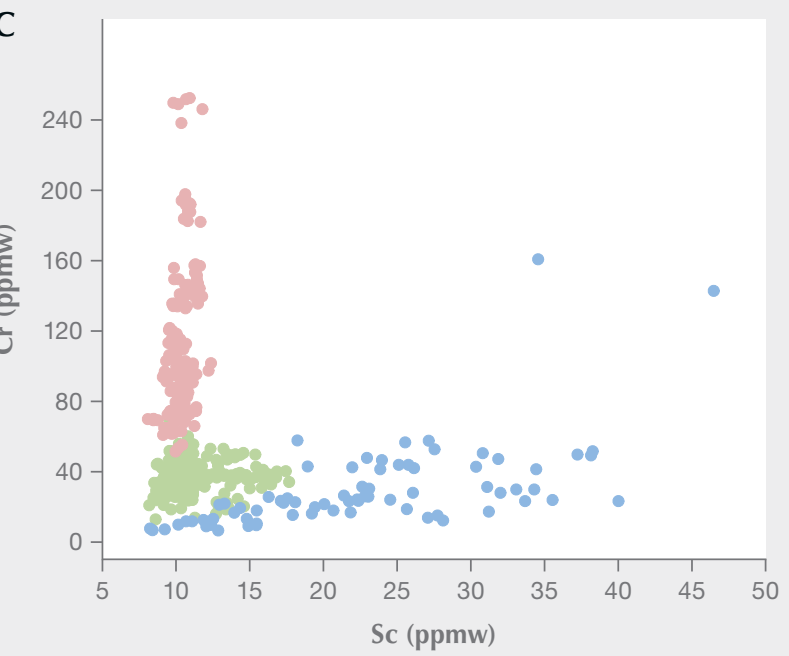

$\mathbf{E}$

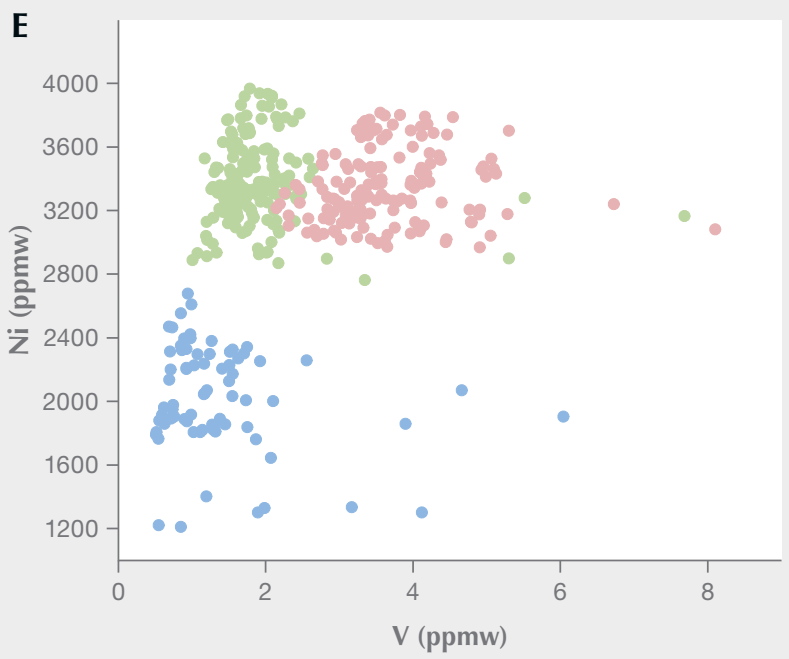

B

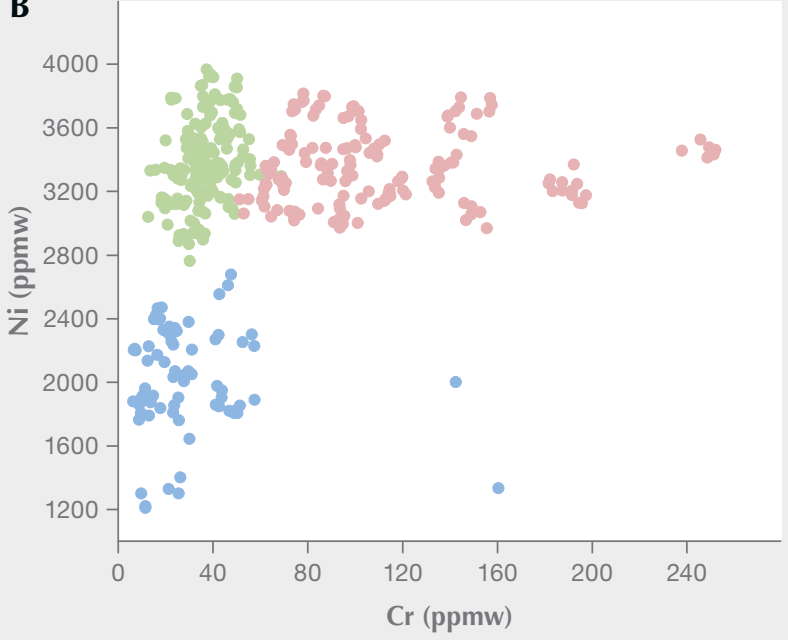

D

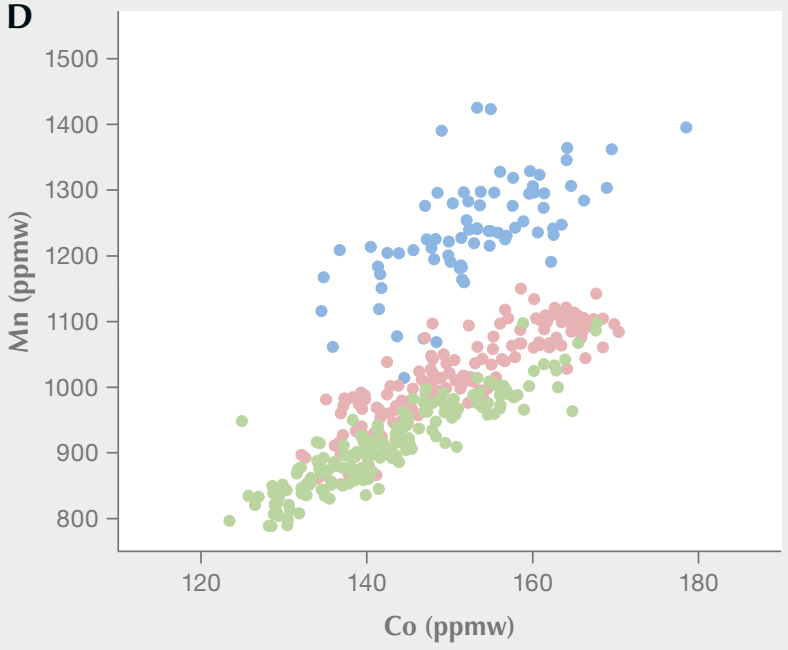

$\mathbf{F}$

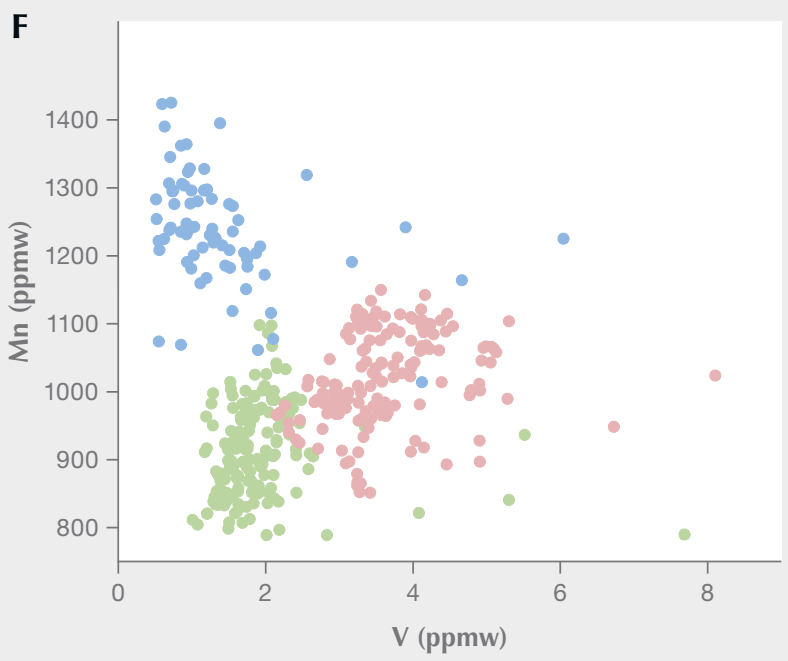

Pyaung-Gaung, Myanmar Yiqisong, China Sapat, Pakistan

Figure 16. 2D scatter plots of trace element contents in peridot from the three geographic origins. 
3D SCATter PlOts
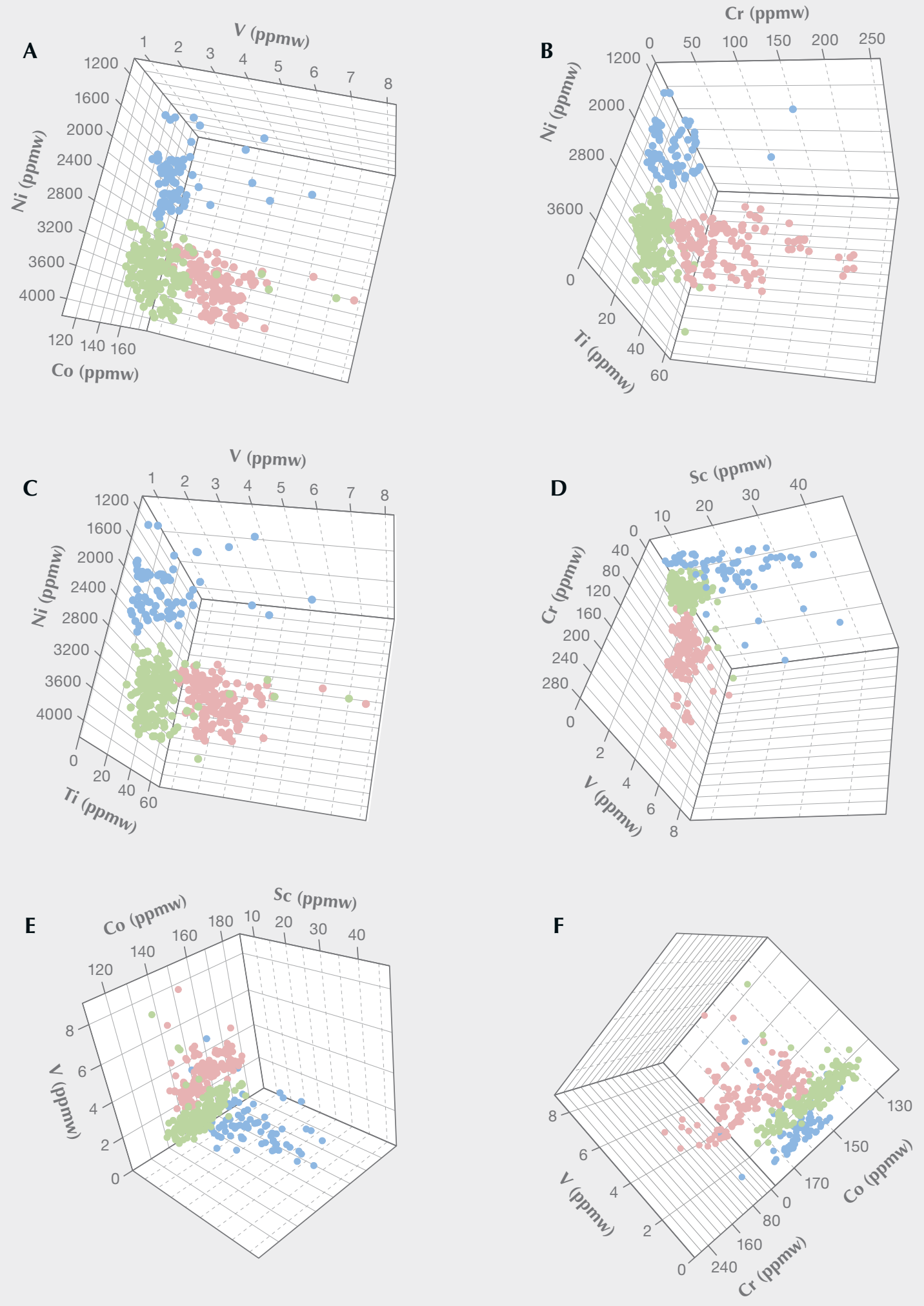

Pyaung-Gaung, Myanmar Yiqisong, China Sapat, Pakistan

Figure 17. 3D scatter plots of trace elements in peridot from the three localities. Plots oriented to show origin separations. 


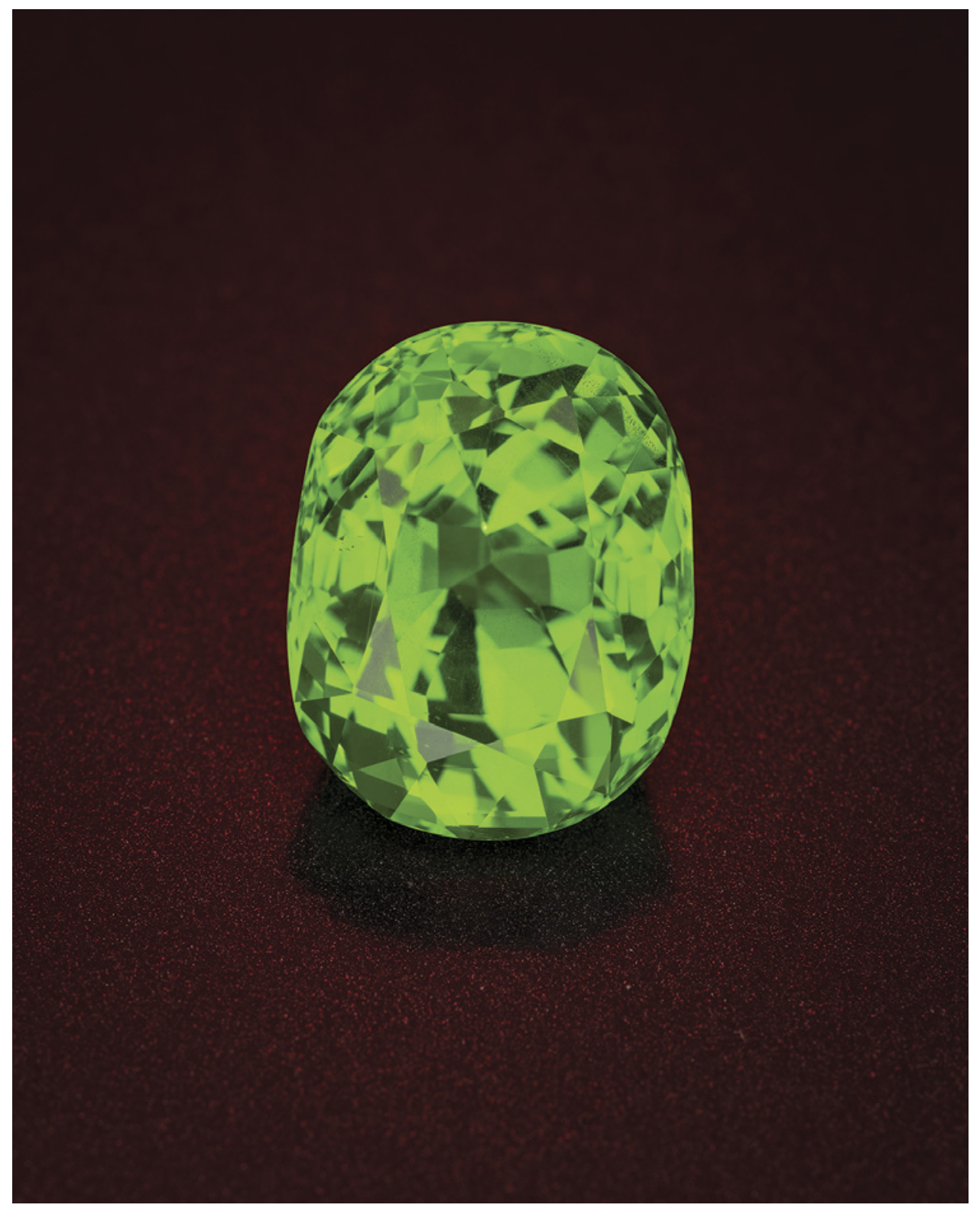

Figure 18. This $17.69 \mathrm{ct}$ oval-cut peridot is from the Bernard-Myo area of Mogok, Myanmar. It is part of the GIA Collection. Photo by Robert Weldon/GIA.

cross-plots showed a positive correlation and proved very useful in separating Pyaung-Gaung peridot from the Yiqisong and Sapat deposits for the samples and reference materials measured. Although overlap may occur between some Pyaung-Gaung and Yiqisong data points in the $2 \mathrm{D}$ plots, the $3 \mathrm{D}$ cross-plots provide a very helpful and straightforward way to determine the origin of peridot from these three deposits. While Ni can be precisely determined using EPMA, this technique is less accurate for other elements at lower concentrations (Shen et al., 2011; Leelawatanasuk et al., 2011). LA-ICP-MS has been proven to be an efficient method for origin determination of these peridot by chemical fingerprinting. However, statis- tical approaches such as discriminant or multivariate analysis may be needed since they can potentially provide additional data to enhance the certainty of the provenance assignment and reduce error.

\section{CONCLUSIONS}

Gemological investigation indicates that Burmese peridot from the Pyaung-Gaung area of Mogok (figure 18) contains tufts of very fine fibers and distinctive protogenetic olivine inclusions. These diagnostic mineral inclusions, as well as inclusions of chromite, magnesite, and chlorite, provide evidence that retrograde metamorphism and/or recrystallization occurred in tension fractures or veinlets during a 
tectonic event. These inclusions can be used as a locality-specific feature for geographic origin determination in combination with chemical analysis by LA-ICP-MS. Based on our data, 2D and 3D crossplots of the trace element contents of $\mathrm{Al}, \mathrm{Sc}, \mathrm{Ti}, \mathrm{V}$, $\mathrm{Cr}, \mathrm{Mn}, \mathrm{Co}$, and $\mathrm{Ni}$ are relatively efficient discriminators to distinguish peridot from the major produc- ing sites of Pyaung-Gaung, Yiqisong (China), and Sapat (Pakistan). However, we used only the data obtained by our own study, in order to control the analytical consistency of reference materials. Additional data and more reliable samples from these and other localities will further refine the provenance assignment of peridot in the future.

\section{ABOUT THE AUTHORS}

Dr. Montira Seneewong-Na-Ayutthaya is a research scientist, and Wassana Chongraktrakul is a gemologist, at GIT in Bangkok. Tasnara Sripoonjan (tasnara@hotmail.com) is a chief gemologist at G-ID Laboratories in Bangkok.

\section{ACKNOWLEDGMENTS}

This research was fully supported by The Gem and Jewelry Institute of Thailand (Public Organization). The authors are grateful to academic advisors Assoc. Prof. Dr. Visut Pisutha-Arnond, Wilawan Atichat, and Prof. Dr. Chakkaphan Sutthirat for their valuable comments and kind review of this article. We greatly appreciate the useful comments and resources from Dr. George E. Harlow from the American Museum of Natural History. Special thanks also go to Thanong Leelawatanasuk (GIT deputy director) and Malin Sawatekitithum (former GIT chief of research and development) for their suggestions and encouragement. We are thankful to Jirapit Jakkawanvibul, Waratchanok Suwanmanee, Yadawadee Kowinthaweewat, and Pattarat Termpaisit for their technical assistance and Dr. Alongkot Fanka for his helpful discussion during the course of this project. Finally, the authors would like to thank Aung Naing Tun and his family for assistance in the field during our trip to Mogok.

\section{REFERENCES}

Adamo I., Bocchio R., Pavese A., Prosperi L. (2009) Characterization of peridot from Sardinia, Italy. $G \uplus G$, Vol. 45 , No. 2, pp. 130-133, http://dx.doi.org/10.5741/GEMS.45.2.130

Barnes S.J. (1998) Chromite in komatiites, 1. Magmatic controls on crystallization and composition. Journal of Petrology, Vol. 39, No. 10, pp. 1689-1720, http://dx.doi.org/10.1093/petroj/39.10.1689

Bouilhol P., Schmidt M.W., Burg J.-P. (2015) Magma transfer and evolution in channels within the arc crust: The pyroxenitic feeder pipes of Sapat (Kohistan, Pakistan). Journal of Petrology, Vol. 56, No. 7, pp. 1309-1342, http://dx.doi.org/10.1093/petrology/egv037

Burns R.G., Huggins F.E. (1972) Cation determination curves for $\mathrm{Mg}$-Fe-Mn olivines from vibrational spectra. American Mineralogist, Vol. 57, No. 5-6, pp. 967-985.

Deer W.A., Howie R.A., Zussman J. (2013) An Introduction to the Rock-Forming Minerals, 3rd ed. The Mineralogical Society, London, pp. 4-11.

Dubinsky E.V., Stone-Sundberg J., Emmett J.L. (2020) A quantitative description of the causes of color in corundum. $G \uplus G$, Vol. 56, No. 1, pp. 2-28, http://dx.doi.org/10.5741/GEMS.56.1.2

Duke D.A., Stephens J.D. (1964) Infrared investigation of the olivine group minerals. American Mineralogist, Vol. 49, No. 910, pp. 1388-1406.

Fritsch E., Lulzac Y. (2004) Gem News International: Arizona peridot with unusual inclusions. $G \uplus G$, Vol. 40, No. 4, pp. 351-352.

Fuhrbach J.R. (1998) Peridot from the Black Rock Summit lava flow, Nye County, Nevada, USA. Journal of Gemmology, Vol. 26, No. 2, pp. 86-102.

GIA (n.d.) Peridot quality factors. Gem Encyclopedia, www.gia.edu/peridot-quality-factor, Jan. 12.

Gübelin E. (1981) Zabargad: The ancient peridot island in the Red Sea. $G \uplus G$, Vol. 77, No. 1, pp. 2-8, http://dx.doi.org/10.5741/GEMS.17.1.2

Gübelin E.J., Koivula J.I. (2004) Photoatlas of Inclusions in Gemstones, 4th ed. Opinio Publishers, Basel, Switzerland, pp. 126127 , pp. 305-308.

Gübelin E.J., Koivula J.I. (2005) Photoatlas of Inclusions in Gemstones, Volume 2. Opinio Publishers, Basel, Switzerland, pp. 511-540.

Harlow G., Thu K. (2014) Peridot from Pyaung-Gaung, Mogok
Tract, Myanmar: Similarities to Sapat and Zabargad deposits. Twelfth Annual Sinkankas Symposium: Peridot and Uncommon Green Gem Minerals, pp. 83-95.

Ishimaru S., Arai S. (2008) Nickel enrichment in mantle olivine beneath a volcanic front. Contributions to Mineralogy and Petrology, Vol. 156, No. 1, pp. 119-131, http://dx.doi.org/10.1007/s00410-007-0277-6

Iyer L.A.N. (1953) The geology and gem-stones of the Mogok Stone Tract, Burma. Memoirs of the Geological Survey of India, Vol. 82, White Lotus Press, Bangkok.

Jan M.Q., Khan M.A. (1996) Petrology of gem peridot from Sapat mafic-ultramafic complex, Sapat, NW Himalaya. Peshawar, Vol. 29, pp. 17-26

Jochum K.P., Weis U., Stoll B., Kuzmin D., Yang Q., Raczek I., Jacob D.E., Stracke A., Birbaum K., Frick D.A., Gunther D., Enzweiler J. (2011) Determination of reference values for NIST SRM 610-617 glasses following ISO guidelines. Geostandards and Geoanalytical Research, Vol. 35, No. 4, pp. 397-429, http://dx.doi.org/10.1111/j.1751-908X.2011.00120.x

Jovanovski G., Makreski P., Soptrajanov B., Kaitner B., Boev B. (2006) Silicate minerals from Macedonia. Complementary use of vibrational spectroscopy and X-ray powder diffraction for identification and detection purposes. Croatica Chemica Acta, Vol. 82, No. 2, pp. 363-386.

Kan-Nyunt H.-P., Karampelas S., Link K., Thu K., Kiefert L., Hardy P. (2013) Blue sapphires from the Baw Mar mine in Mogok. GњG, Vol. 49, No. 4, pp. 223-232, http://dx.doi.org/10.5741/GEMS.49.4.223

Kane R.E., Kammerling R.C. (1992) Status of ruby and sapphire mining in the Mogok Stone Tract. $G \uplus G$, Vol. 28, No. 3, pp. 152-174, http://dx.doi.org/10.5741/GEMS.28.3.152

Kelemen P.B., Hirth G. (2012) Reaction-driven cracking during retrograde metamorphism: Olivine hydration and carbonation. Earth and Planetary Science Letters, Vol. 345-348, pp. 81-89, http://dx.doi.org/10.1016/j.eps1.2012.06.018

Koivula J.I. (1981) San Carlos peridot. GÆG, Vol. 17, No. 4, pp. 205-214, http://dx.doi.org/10.5741/GEMS.17.4.205

Koivula J.I., Fryer C.W. (1986) The gemological characteristics of Chinese peridot. $G \uplus G$, Vol. 22, No. 1, pp. 38-40, 
http://dx.doi.org/10.5741/GEMS.22.1.38

Kyaw Thu (2007) The igneous rocks of the Mogok Stone Tract: Their distribution, petrography, petrochemistry, sequence, geochronology and economic geology. Ph.D. thesis, Yangon University, Yangon, Myanmar, $139 \mathrm{pp}$.

Lafay R., Montes-Hernandez G., Renard F., Vonlanthen P. (2018) Intracrystalline reaction-induced cracking in olivine evidenced by hydration and carbonation experiments. Minerals, Vol. 8, No. 412, pp. 1-18, http://dx.doi.org/10.3390/min8090412

Leelawatanasuk T., Atichat W., Sutthirat C., Wathanakul P., Sriprasert B., Naruedeesombat N., Srithunayothin P., Davies S. (2011) Pallastic peridot: The gemstone from outer space. Proceedings of the 32nd International Gemmological Conference, Interlaken, Switzerland, July 13-17, pp. 110-113.

Lin N. (2014) Structural deformation of the Momeik-Myitson area, Momeik township: Criteria for tectonics. Yadanabon University Research Journal, Vol. 5, No. 1, pp. 1-9.

Patil P., Mookherjee A., Marathe T., Sastry T.N. (2017) Inclusions in rubies from South India. International Journal of Advance Research in Sciences and Engineering, Vol. 6, No. 11, pp. 714735.

Phyo M.M., Bieler E., Franz L., Balmer W., Krzemnicki M.S. (2019) Spinel from Mogok, Myanmar-A detailed inclusion study by Raman microspectroscopy and scanning electron microscopy. Journal of Gemmology, Vol. 36, No. 5, pp. 418-435.

Salem A.K.A., Khalil A.E., Ramadan T.M. (2012) Geology, geochemistry and tectonic setting of Pan-African serpentinite of Um Salim-Um Salatit area, Central Eastern Desert, Egypt. The Egyptian Journal of Remote Sensing and Space Science, Vol. 15, pp. 171-184.

Shen A.H., Koivula J.I., Shigley J.E. (2011) Identification of extraterrestrial peridot by trace elements. Ge G, Vol. 47, No. 3, pp. 208-213, http://dx.doi.org/10.5741/GEMS.47.3.208

Sinkankas J., Koivula J.I., Becker G. (1992) Peridot as an interplanetary gemstone. $G \uplus G$, Vol. 28, No. 1, pp. 43-51, http://dx.doi.org/10.5741/GEMS.28.1.43

Sripoonjan T., Saengbuangamlam S., Leelawatanasuk T. (2017) GIT 2016 Pre-conference field trip to Mogok, Myanmar, November 2016. Journal of Gemmology, Vol. 35, No. 5, pp. 436-443.

Sripoonjan T., Seneewong-Na-Ayutthaya M., Bupparenoo P., Narudeesombat N., Leelawatanasuk T., Sawatekitithum M.
(2019) Gemmological and chemical characteristics of Yiqisong peridot, Jilin, People [sic] Republic of China. Proceedings of the 36th International Gemmological Conference IGC, Nantes, France, August 27-31, pp. 92-95.

Stockton C.M., Manson D.V. (1983) Peridot from Tanzania. Get)G, Vol. 19, No. 2, pp. 103-107, http://dx.doi.org/10.5741/GEMS.19.2.103

Surour A.A. (2018) A Note on the chemical composition and origin of peridot from the Harrat Kishb, Saudi Arabia. Geosciences Research, Vol. 3, No. 4, pp. 65-73, http://dx.doi.org/10.22606/gr. 2018.34003

Themelis T. (2008) Gems $\nrightarrow$ Mines of Mogok. A\&T Publishing, 325 pp.

Thu K. (2007) The igneous rocks of the Mogok Stone Tract. Ph.D. Dissertation, University of Yangon, Myanmar.

Thu K., Harlow G.E. (2017) Hydrothermal recrystallization of dunitic olivine in peridotite from Pyaung-Gaung Mogok Myanmar: Similarities to Sapat and Zabargad deposits. Inaugural Conference on Applied Earth Sciences in Myanmar and Neighboring Regions, Myanmar Applied Earth Sciences Association (MAESA), Yangon, Myanmar, November 2-3.

Thu K., Zaw K. (2017) Gem deposits of Myanmar. In A.J. Barber et al., Eds., Myanmar: Geology, Resources and Tectonics. Geological Society Memoir No. 48, Geological Society of London, pp. 497-529.

Thuyet N.T.M., Hauzenberger C., Khoi N.N., Diep C.T., Lam C.V., Minh N.T., Hoang N., Hager T. (2016) Peridot from the Central Highlands of Vietnam: Properties, origin, and formation. $G \uplus G$, Vol. 52, No. 3, pp. 276-287, http://dx.doi.org/10.5741/GEMS.52.3.276

Tzamos E., Bussolesi M., Grieco G., Marescotti P., Crispini L., Kasinos A., Storni N., Simeonidis K., Zouboulis A. (2020) Mineralogy and geochemistry of ultramafic rocks from Rachoni magnesite mine, Gerakini (Chalkidiki, northern Greece). Minerals, Vol. 10, No. 11, article no. 934, https://doi.org/10.3390/min10110934

Waltham T. (1999) The ruby mines of Mogok. Geology Today, Vol. 15, No. 4, pp. 143-149, http://dx.doi.org/10.1046/j.13652451.1999.1504007.x

Zhang Z., Ye M., Shen A.H. (2019) Characterization of peridot from China's Jilin Province and from North Korea. Journal of Gemmology. Vol. 36, No. 5, pp. 436-446. 